\title{
CALCINE CONVERSION FACILITY \\ ALTERNATIVE CONCEPTS \\ ENGINEERING STUDIES
}

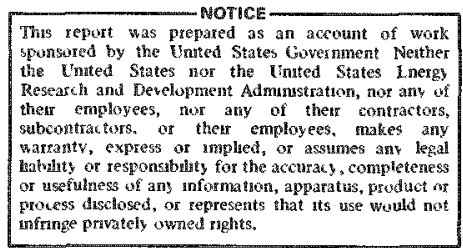

Atlantic Richfield Hanford Company

Kaiser Engineers

Battelle Pacific Northwest Laboratory

February 1975

Prepared for the

Energy Research and Development Administration by Atlantic Richfield Hanford Company under Contract AT $(45-1)-2130$ 


\section{DISCLAIMER}

This report was prepared as an account of work sponsored by an agency of the United States Government. Neither the United States Government nor any agency Thereof, nor any of their employees, makes any warranty, express or implied, or assumes any legal liability or responsibility for the accuracy, completeness, or usefulness of any information, apparatus, product, or process disclosed, or represents that its use would not infringe privately owned rights. Reference herein to any specific commercial product, process, or service by trade name, trademark, manufacturer, or otherwise does not necessarily constitute or imply its endorsement, recommendation, or favoring by the United States Government or any agency thereof. The views and opinions of authors expressed herein do not necessarily state or reflect those of the United States Government or any agency thereof. 


\section{DISCLAIMER}

Portions of this document may be illegible in electronic image products. Images are produced from the best available original document. 
TABLE OF CONTENTS

Tit $1 e$

Page

1.0 INTRODUCTION 1

1.1 BACKGROUND 1

1.2 PURPOSE OF THE STUDY 2

2.0 SUMMARY COMPARISON OF TWO CCF CONCEPTS 3

2.1 OBJECTIVES

2.2 FUNCTIONAI REQUIREMENTS

2.3 DESIGN BASES AND PERFORMANCE CRITERIA

2.4 CCF/RSSF DESCRIPTION 6

2.4.1 Facility Description 6

2.4.2 Process Description 6

2.4.3 Technology 7

2.4.4 Safety Considerations 7

2.5 CCF/FRP FACILITY DESCRIPTION 7

2.5.1 Facility Description 7

2.5.2 Process Description 8

2.5.3 Technology 8

2.5.4 Safety Considerations 8

2.6 COSTS 8

3.0 PRINCIPAL DESIGN BASES 9

3.1 FORM OF RECEIVED WASTE 9

3.2 INCOMING LAG STORAGE 9

3.3 AGE OF RECEIVED WASTE 9

3.4 CONVERSION RATES 10

3.5 DISPOSITION OF CONVERTED WASTE 10

3.6 TEMPERATURE RATE IIMITS OF CALCINE 10

3.7 TEMPERATURE RATE IIMITS FOR GLASS

3.8 PRODUCT AND CANISTER CRITERIA 10

3.9 STRUCTURE AND SYSTEM DESIGN CLASSIFICATION 10

3.10 USE OF PROVEN TECHNOLOGY 11

3.11 CONFINEMENT OF RADIOACTIVE MATERIALS 11

3.11.1 Normal Operating Conditions 11

3.11.2 Abnormal Operating Conditions 11

3.11.3 Design Basis Conditions 11

3.11.4 Contamination Control 12 
TABLE OF CONTENTS (Continued)

Title

$\underline{\text { Page }}$

3.12 MULTIPLE CONFINEMENT BARRIERS 12

3.13 RADIATION PROTECTION 12

3.14 RECOVERY FROM EMERGENCY CONDITIONS 12

3.15 EMERGENCY PLANNING 13

3.16 COMPLIANCE WITH REGULATIONS, CODES AND STANDARDS

3.16.1 Code of Federal Regulations 13

3.16.2 State and Local Regulations 14

3.16 .3 Codes and Standards 14

4.0 CONCEPT DESCRIPTIONS 15

4.1 GENERAI FEATURES COMMON TO BOTH
CCF CONCEPTS

4.1.1 Receiving Facilities 15

4.1.2 Water Basin Storage 15

4.1.3 Utilities 16

4.1.4 Support Facilities 17

4.2 CCF/RSSF CONCEPT 18

4.2.1 Functional Design Bases 18

4.2.2 Facility Equipment Arrangement 18

4.2.3 Operational Description 19

4.2.4 Maintenance and Repair 21

4.2.5 Sample Analysis 22

4.3 CCE/FRP CONCEPT 22

4.3.1 Functional Design Bases 22

4.3.2 Facility and Equipment Arrangement 22

4.3.3 Operational Description 23

4.3.4 Maintenance and Repair 24

4.3.5 Waste Disposal 24

5.0 TECHNICAL ANALYSIS 26

5.1 WASTE CHARACTERISTICS 26

5.2 PLANT CAPACITY AND AGE OF WASTE 27

$5.2 .1 \mathrm{CCF} / \mathrm{RSSF} \quad 27$

5.2 .2 CCF/FRP $\quad 29$

5.3 WASTE ACCEPTANCE CRITERIA 32 


\section{ii i}

TABLE OF CONTENTS (Continued)

Title

Page

5.4 SITE DESCRIPTION

5.4.1 Location

32

5.5 SHIELDING

35

5.6 GLASS CHARACTERISTICS

35

6.0

SAFETY ANALYSIS

36

6.1 INTRODUCTION

36

6.2 NORMAL OPERATING CONDITIONS

38

6.3 ABNORMAL OPERATING CONDITIONS

38

6.4 IMPROBABLE EVENTS

39

6.5 ATMOSPHERIC DISCHARGES

39

6.6 LIQUID WASTES

6.7 SOLID WASTES

40

40

7.0 ENVIRONMENTAL ASSESSMENT

41

8.0 CAPITAL COST ESTIMATES AND CONSTRUCTION SCHEDULES

8.1 CAPITAL COST

8.2 CONSTRUCTION SCHEDULE

9.0 OPERATING COSTS

DRAWINGS

DISTRIBUTION 


\subsection{INTRODUCTION}

\subsection{BACKGROUND}

The Federal government will assume permanent custody of all high level radioactive waste generated by commercial nuclear fuel reprocessing plants, in accordance with Code of Federal Regulations, Title 10, Part 50, Appendix $F_{\text {. These wastes }}$ must be solidified within 5 years and shipped to a Federal repository within 10 years after fuel reprocessing.

Ultimate disposal concepts and ultimate disposal sites have not been selected. Their selection is not expected to be complete in time for use in the disposal of the first solidified wastes generated by the commercial fuel cycle. Therefore, the Federal government (will undertake the design and construction of a Retrievable Surface Storage Facility that will store the solidified radioactive wastes until a permanent disposal facility becomes available.

The least expensive and simplest method of solidification of the wastes is to convert it to a calcine. However, calcine is partially soluble in water, and fine particles might become airborne if they should escape the confinement barriers of the storage system. The RSSF system is designed to safely store calcine: however, the technology is available for converting the calcine to a glass* form which is less dispersible to the environment. Furthermore, conversion to a glass form would eliminate the need to resolve questions about the long term stability of calcine.

If it is determined that the glass form is indeed preferred over calcine, then commercial reprocessors should add a calcine-to-glass conversion process to their plants as soon as the process and equipment have been demonstrated. A government-owned Calcine Conversion Facility (CCF) would serve to develop and demonstrate a licensed conversion process which could be transferred to industry.

* The product of the CCF process will be referred to as "glass" throughout this document. It may be either glass or ceramic and will contain calcine chemically incorporated in the solid matrix. 


\subsection{PURPOSE OF THE STUDY}

Tue purpose of the engineering study reported in tlis document is to develop conceptual designs for two alternative facilities for the conversion of hicil level waste calcine to high level glass. The document describes the objectives and design bases of the two concepts. A brief physical description of the facilitios and a brief roview of technical and engineering considerations are also given. Capital cost estimates are provided, however comparative costs tend to be misleading because the two concepts are not truly comparable either in overall value to the nuclear fuel cycle or in their dependence on related facilitics.

No recommendation of one concent in preference to the otier is contained in this document and a sincere effort has been made to avoid establishment of a bias in either dircction. 


\subsection{SUMMARY COMPARISOJ OF TWO CCF CONCFNTS}

lugineering studies have been made of two alternative facilities for the conversion of calcine to a glass prociuct. A basic objective of both facilitins is to demonstrate calcine/ glass conversion technology. rhis will assist the owners of commercial fuel renrocessing plants in desiming and installing their own conversion facilities at a later date.

One alternative facility, referred to as the CCF/PSSF, wnuld be located at the RSSF. The CCF/RSSF would accept calcine from the RSSF and return it as a glass product suitable for long term storage.

The other alternative facility, referred to as the CCF/FPP, would be located adjacent to a Fuel Reprocessind plant. The CCF/FRP would accent calcine directly fron the FRP. After conversion to a glass product the waste would be stored in a water basin at the FR until drcayed to an ontimum activity level for shimment to the RSST.

\subsection{OBJT:COIVTS}

The current ohiectives for both cry facjlitins are to demonstrate the followind:

a. Calcine/glass conversion process i.s frasiblo on a produrtion scale, and can be licensed.

b. Product ruality and uniforinty can ve controlled.

c. Production operation can be conducted sefel: and efficiently.

d. Production of a glass product can be accomplished without damaie to man or the cnriromment.

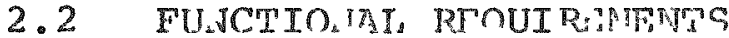

The major functional remiremonts of thr $\mathrm{CCF}$ nay he summarized as follows:

a. CCF/LSSF will recejve calcine fillc l canisters from the RSGF. CCF/FPD will receive loose calcjno direct from the FRP.

b. CCF/RSsF will proviule safe storare of cunistres recoived during a period of un to 6.3 dass. 


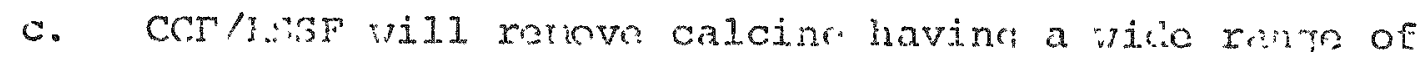
binyiarl mronoties Exom canisters.

d. Pransiort, bleno, melt, chat anci anmol. the calcine arr rlass matorial.;.

e. Tngent and test tie nor containnent canister.

f. uranfor the rlass filled canistur to the pa, mond m? test coll or the Pnp water wasin for storare.

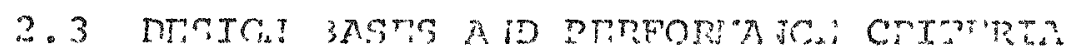

Whe bases and the serforrance criteria use? for cry cositn are survarized in this scction; exmancel reruirenmes aro enumerated in section 3.\%.

- The CCP/ISSF lesign shall so based on roceiving calcino in canjsters $12.75^{\prime \prime}$ ou $\& 15^{\prime}$ overall lenth containin!" $9.4 \mathrm{ft}^{3}$ of calcine. The cotpro will receive lonse calcine directly from the Fro via a morar transfex device.

- romal srocessing rates stall bo achieved with 5 -yearold waste in the CCF/RSSF and 1-vearmold waste in tive CCF/FRP. Younger wastes may be processed in cither Eacility on a demonstration basis with no production rate recuirements.

- The desimed processind rate of the CCF/RssF shall errual the calcine vroduced hy an \& Mrul per day Frp. The CCF/FPP shall be lesimed to process the calcine from a 5 MTU per dav PRP.

- The handing and process ecuimment shall be desioned to initially handle $12.75^{\prime \prime}$ on $\times 15^{\prime}$ lonn canistors. The structure sha11 be desianed to handle canisters from $6^{\prime \prime}$ on to $24^{\prime \prime}$ on $\times 15^{\prime}$ long after modification of process and handling eruipment.

0

- The facilities shall be licensed in accorcance with the appropriate Federal Rerulations. M11 safety and environmental requirements shall be met.

- The CCF/RSSF shall be adjacent to the RSSF and use the RSSF receiving facilities. The CCF and $R S S F$ shall share utilities and services where it is practical and safe to do so. 
- The CCF/FRP shall be adjacent to an FRP and use the waste canister storage facilities provided by the FRP. The CCF and FRP shall share utilities and services where practical.

- The product of the CCF shall be a glass material sealed in a metallic canister suitable for packaging for storage in the RSSF.

\section{4 CCF/RSSF DESCRIPTION}

\subsubsection{Facility Description}

In the present study the CCF/RSSF is a facility to be built adjacent to the RSSF receiving facility. If both facilities were designed and constructed simultaneously they could be totally integrated in a single structure. However there is a strong possibility that their construction schedules will not match: therefore, it is necessary to consider them as separate facilities that share the same site and use common services wherever practical.

The RSSF and the CCF/RSSF will be connected by a water canal between the structures to permit transfer of canisters of waste between facilities. Some common facilities are to be shared.

The conversion is performed in a series of concrete shielded process cells. Equipment and processes within the cells are controlled from an adjacent operating gallery. Shielding windows within the cell walls permit process observation. Manipulators are provided for minor adjustments and maintenance. Major material handling is performed by in-cell cranes and all process operations are controlled remotely from the operating gallery.

\subsubsection{Process Description}

The calcine is received in sealed canisters that are opened and emptied into a blender in the decanning cell. In the blender the calcine is mixed with glass forming materials. "frit". The mixture is then returned to the original canister, which has been placed in an electric furnace where the temperature is raised to the molten mixture temperature (about 1,000 ${ }^{\circ} \mathrm{C}$ ). To avoid thermal shocks and resultant cracking of 
the glass product, the canister of glass is cooled at a controlled rate. If the used canisters are judged unfit for reuse or more are required due to increased volume of the glass over the calcine, new canisters are introduced as required.

The canisters of glass are sealed by welding, checked for leakage, and decontaminated prior to return to the RSSF via the water canal.

\subsubsection{Technology}

The basic technology for the manufacture of glass from a variety of components is well understood and is in use in the commercial glass industry. Battelle Northwest Laboratory is currently adapting this technology to the conversion of radioactive calcine to glass.

\subsubsection{Safety Considerations}

The addition of a glass conversion process to the waste storage cycle introduces new steps and new risks. The new risks are those occasioned by the high temperatures required to melt the glass and the potential for contamination spread when the waste canisters are opened and the loose calcine is handled. These processing risks are controllable by proper facility design.

\subsection{CCF/FRP GACILITY DESCRIPTION}

\subsubsection{Facility Description}

The CCF/FRP will be built adjacent to an existing fuel reprocessing plant and will receive loose calcine directly from the FRP. This structure may contain the calciner and the waste storage basin which are totally the responsibility of the $\mathbb{F} R P$.

The CCF/FRP will share facilities and services with the FRP wherever practical.

The conversion is performed in a series of concrete shielded process cells similar to those of the CCF/RSSF. However. fewer cells are required because the decanning and canister reuse operations have been deleted, and the CCF effluents will be routed to the FRP. 


\subsubsection{Process Description}

The conversion process at the CCF/FRP will be identical to that of the CCE/RSSF. The CCF/FRP will also use the same equipment except that the younger waste of the CCF/FRP will require the removal of about six times as much decay heat from comparable quantities of solidified waste.

\subsubsection{Techrology}

The CCF/FRP will use the same technology as the CCF/RSSF.

\subsubsection{Safety Considerations}

The conversion process for the CCF/FRP and the CCF/RSSF wiII introduce the same risks during the conversion operation: however, the consequences will be greater with the CCF/FRP because of the younger waste. The additional risk is compensated for by the fact that the waste will be reduced to a glass form at about 1 year of age compared to 5 years age for the CCF/RSSF. This 4 years' difference covers a period of highest radioactivity and decreased dispersibility during this period reduces the overall risk.

\section{6 cosTs}

Cost estimates have been developed based on the design described in this document. The estimated total project costs, including contingency and escalation, axe $\$ 80$ miliion for the $\mathrm{CCF} / \mathrm{RSSF}$ and $\$ 60$ million for the $\mathrm{CCF} / \mathrm{FRP}$. 


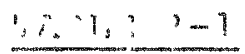

SUIMARY CORPARISON DF TWO CCF COINLPAS

\begin{tabular}{|c|c|c|}
\hline & $\mathrm{CCH} / \operatorname{RSST}$ & $\mathrm{CCr} / \mathrm{FRP}$ \\
\hline $\begin{array}{l}\text { Program } \\
\text { Objectives }\end{array}$ & $\begin{array}{l}\text { Denonstrate feasi- } \\
\text { bility of production } \\
\text { scale conversion } \\
\text { Demonstrate safo pro- } \\
\text { cess, Tuality pro- } \\
\text { duct, no environ- } \\
\text { mental damage. } \\
\text { Provide technolog- } \\
\text { ical bases for } \\
\text { licensing Euture ccF's } \\
\text { Minimize calcine backm- } \\
\text { log accumulation }\end{array}$ & Same \\
\hline $\begin{array}{l}\text { Design } \\
\text { Bascs }\end{array}$ & 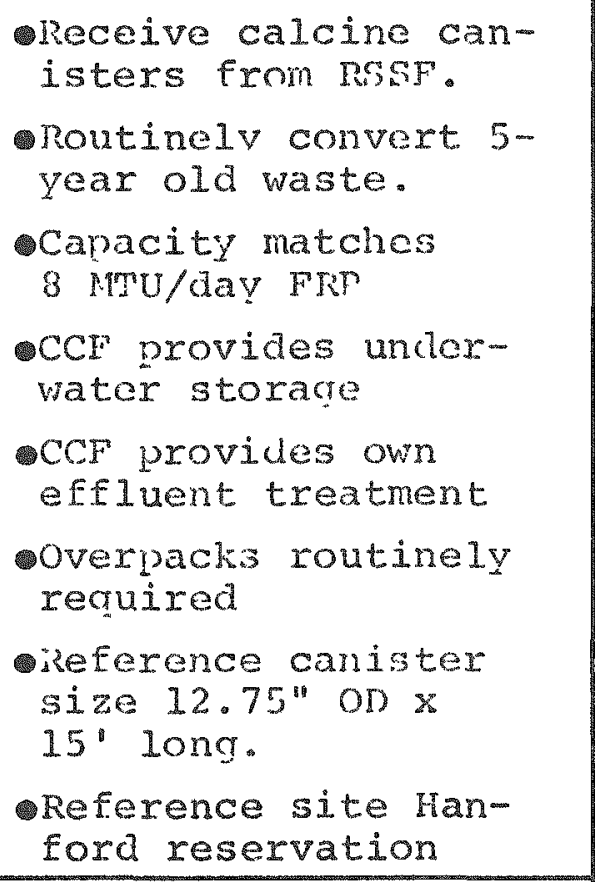 & 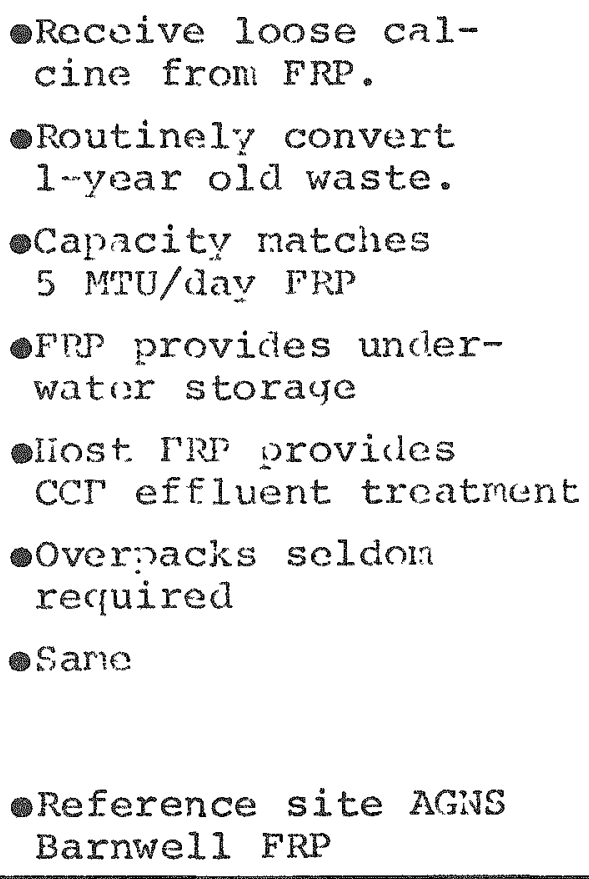 \\
\hline Cells & - 4 plus transfer & - 3 plus transfer \\
\hline Scnedule & liot startup Jan. 1933 & - Same \\
\hline Cost & $\$ 76,007,000$ & $.056,000,000$ \\
\hline
\end{tabular}




\subsection{PRINCIPAL DESIGN BASES}

This section provides the principal design bases in the detail appropriate to the present design study effort. Subsequent sections provide a description of the two facilities. Certain of the design bases apply equally to both of the CCF concepts while others apply to only one concept or are different for the two concepts. The conditions are reflected in the following "design bases".

\subsection{FORM OF RECEIVED WASTE}

The waste to be converted by the CCF will be a stable, ary, solid, high level radioactive calcine as described in $10 \mathrm{CF}$ 50. Appendix F.

The waste will arrive at the CCF/RSSF sealed in stainless steel canisters nomina11y 12.75 inches outside diameter by 15 feet 1ong: however, the size may vary from 6 to 24 inches in diameter and lengths from 10 to 15 feet.

Waste will be received at the CCF/FRP as a loose calcine material as discharged from the FRP calciner.

\subsection{INCOMING IAAG STORAGE}

The CCF/RSSF shall have a water storage basin capable of storing 160 canisters to permit segregation of receipts from several FRP, and provide lag storage for incoming canisters of calcine during CCF shutdowns.

\subsection{AGE OF RECEIVED WASTE}

The CCF/RSSF shall be designed, to routinely process waste as young as five years out of the reactor. The facility shall also be capable of processing limited quantities of waste as young as three years under special conditions.

The CCF/FRP shall be designed to routinely process waste as young as one year out of the reactor. It shall also be capable of processing limited quantities of waste as young as six months out of the reactor.

The operation of either facility must also result in data that can be extrapolated to design a CCF that can process waste as young as six months out of the reactor as a routine. Eullscale operation. The basis for the difference in the age of waste for routine processing is discussed in section 5.2 . 


\subsection{CONVERSION RATES}

The CCF/RSSF shall be designed to convert the calcine generated by the reprocessing of 8 tonnes of uranium fuel per day $(2,400$ tonnes per year). The CCF/FRP shall be designed to convert the calcine generated by the reprocessing of 5 tonnes of uranium fuel per day (1,500 tonnes per year).

\subsection{DISPOSITION OF CONVERTED WASTE}

Sealed canisters of glass waste from the CCF/RSSF shall be transferred immediately to the RSSF where they will be sealed in casks for long term storage. Sealed canisters of glass waste from the CCF/FRP shall be placed in the FRP waste storage basin for additional radioactive decay prior to shipment to the RSSF.

\subsection{TEMPERATURE RATE IIMITS FOR CALCINE}

The decay heat from the calcine must be removed continuously to prevent overheating of the calcine and processing equipment prior to entering the melter. However, the time and temperature rise limits are still to be determined.

\subsection{TEMPERATURE RATE LIMITS FOR GLASS WASTE FORMS}

Temperatures of waste in process must reach the molten temperature during processing. After the annealing step is complete, the maximum rate of temperature change shall not be permitted to exceed $25^{\circ} \mathrm{C}\left(45^{\circ} \mathrm{F}\right)$ per hour.

\subsection{PRODUCT AND CANISTER CRITERIA}

Criteria for the glass product, glass canister, and calcine canister are in the process of being developed.

\subsection{STRUCTURE AND SYSTEM DESIGN CLASSIFICATION}

structures and systems shall be classified as to their importance to the safety and operability of the CCF. The following classifications shall be used in establishing design requirements and quality assurance levels of effort:

Class I - Those structures and systems whose failure could cause the release of excessive amounts of radioactivity. or that are essential to safe shutdown. 
Class II - Those structures and systems important to the operation of the CCF but not essential to safe shutdown.

Class III - Those structures and systems whose failure will not result in release of excessive amounts of radioactivity and whose operation is not essential to the CCF.

\subsection{USE OF PROVEN TECHNOLOGY}

The CCF is a near-term facility and must use existing technology, or technology that can be extended to meet CCF requirements with a high degree of confidence.

\subsection{CONFINEMENT OF RADIOACTIVE MATERIALS}

The CCF shall be designed for safe confinement, under all credible conditions, of all radioactive waste received at the facility.

\subsubsection{Normal Operating Conditions}

Under normal operating conditions, the release rate of radioactive material to the environs shall not exceed 10 percent of the amounts permitted in $10 \mathrm{CFR} 20$ for individuals and population groups in uncontrolled areas. The anticipated temporary malfunction of equipment or systems which require repair or replacement are considered to be "normal".

\subsubsection{Abnormal Operating Conditions}

Abnormal operating conditions might result from equipment failures, operating errors, or unplanned process variations that might occur sometime during the plant operating life.

Under abnormal operating conditions, the release rate of radioactive material to the environs shall not exceed the amounts permitted in $10 \mathrm{CF} 20$ for individuals and population groups in uncontrolled areas.

\subsubsection{Design Basis Conditions}

Under design basis (maximum credible) accident conditions or natural phenomena, exposure to the general public as a result of the escape of radioactive material shall not exceed $2.5 \mathrm{rem}$, which is 10 percent of the exposure reference values stated in 10 CFR 100, paragraph 100.11. 
Design basis accident and natural phenomena are highly improbable events which are not expected to occur during the plant operating life; however, design features which further reduce the probability and possible magnitude of waste confinement loss resulting from these events are justified by their potential consequences and shall be included. The design basis natural phenomena shall be determined for the CCF site as described in $10 \mathrm{CFR} 100$ and Design Guide 1.76.

\subsubsection{Contamination Control}

To the extent practicable, the facility will be operated "contamination free" outside of the cells. The design shall accommodate this philosophy by providing: (1) surfaces which can be easily decontaminated; (2) a decontamination system; and (3) isolation of high risk processes from those processes that are inherently less apt to release contamination to work areas.

\subsection{MULTIPLE CONFINEMENT BARRIERS}

At least two barriers shall be provided on any possible escape routes between stored or in-process waste and the environment.

Where either calcine or glass waste is in a sealed canister, the canister may be treated as one of the barriers. The second barrier may be an overpack, transport cask, cell or a series of components made up of water, heat exchangers, filters, and piping.

Where the canister does not form a confinement barrier, equivalent confinement functions shall be provided by the use of additional process enclosures such as storage bins and a process off-gas system.

\subsection{RADIATION PROTECTION}

shielding shall be provided to protect plant personnel from all sources of radiation to assure their radiation exposure is within the requirements of $10 \mathrm{CFR} 20$. Interlocks and automatic detection alarms shall be used to prevent personnel from entering high radiation zones and to warn them of high radiation levels.

\subsection{RECOVERY FROM EMERGENCY CONDITIONS}

A number of abnormal events can be expected to occur during the lifetime of the CCF and there is a probability that 
accidents will occur. In acldition to showing, by safety analysis, that such events will not cause unclue risk to the health and safety of the vublic or plant personnel, it must be shown that the facility can be returned to normal after any abnormal event or design basis accident.

The probability of the simultaneous occurrence of two design basis events is not considexed credible and need not be covered by the ccF design. However, assuming the occurrence of a single design basis event, it shall be practical to place the CCF in a condition to withstand a second design basis event within $3 n$ days aftor the first event. The second event may be a reneat of the first event or any of the other design basis events.

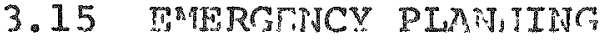

Fmergency lanning reruiraments, ineludinc space for storage of emergency eruimment, shall he considexed during desion to assure (1) that the facilit; features provide for ease of evacuation and other emerrency recuirements and are coorilnated with the overal1 ilant complox emerrency plat, and (2) compliance with in CWR 20.

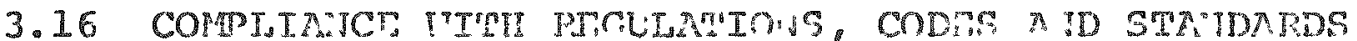

The CCF will be a licensed facility complyinm with fedoral, state and local regulations. The design and the manufactured and structural components of the installation shall comply with applicable national codes and standards. Txceptions shall be noted and the basis for the criteria used documented.

Following is a tabulation of the requlations, codes and standards considered apnlicabls to the ccr. Complance vith additional criteria referenced theroin is recuired as applicable.

3.16.1 Code of Foderal perulations

- Title 10, Part 20, "Stadardr for Protection Mrainst Radiation"

- Title 10, Part 3n, "Pulas of General. Applicabilit"? to Licensing Byproduct "atorial"

- Pitle 12, Part 4n, "Licensing of Source Material"

Witle 10, Part 51, "Licensing and Regulatory Polirss" and Procedures for Environmental protrction" 
- Title 10, Part 70, "Special Nuclear Material"

Title 10, Part 71, "Packaging of Radioactive Material for Transport and Transportation of Radioactive Material Under Certain Conditions"

- Title 10, Part 73, "Physical Protection of Plants and Materials"

\subsubsection{State and Local Regulations}

Applicable state and local regulations and ordinances shall be determined for each site. Compliance is required if these are more restrictive than Federal regulations.

\subsubsection{Codes and standards}

The Atomic Energy Commission "Regulatory Guides" shall be used to implement the requirements in the referenced Parts of the Code of Federal Regulations. National codes and standards are referenced in the Regulatory Guides and compliance is required.

The design and fabrication requirements specified in the following sections of the American Society of Mechanical Engineers Boiler and Pressure Vessel Code (ASME Code) shall be used as applicable:

- Section II, "Material Specifications"

- Section III, "Nuclear Power Plant Components"

- Section V, "Nondestructive Examination"

- Section VIII. "Pressure Vessels" (Division 1)

- Section IX, "Welding Qualifications"

An ASME "N" stamp is not required for any components. 


\subsection{CONCEPT DESCRIPTIONS}

Both of the alternative CCF designs are described in this section. General reatures shared by both CCF designs are discussed in 4.1. Specific functional design requirements and concept descriptions pertinent to the individual CCF concepts are then discussed in following subsections.

\subsection{GENERAL FEATURES COMMON TO BOTH CCF CONCEPTS}

\subsubsection{Receiving Facilities}

Neither CCF concept requires receiving facilities for rail or truck shipments of calcine in shielded shipping casks. In the case of the CCF/FRP. calcine comes to the CCF via pipeline from the host plant. In the case of the CCF/RSSF, the RSSF provides the receiving facilities and transports calcine canisters to the CCF via a water canal, as illustrated in Drawings 7238-100-AR-1 (Plans) and 7238-100-AR-2 (Sections).

\subsubsection{Water Basin Storage}

Water basin storage facilities are requixed for both concepts, but for different reasons.

- The CCE/FR requires water basin storage facilities for canisters of glass in order to remove decay heat until the canisters heat output is low enough to permit economical shipping to the RSSF. This storage basin will be provided by the host FRP.

- The CCF/RSSF requires water basin lag storage facilities for incoming calcine canisters from the RSSF, to permit segregation of calcine from the various reprocessors until enough calcine has accumulated for an economical batch run of each type of calcine. Iag storage is also needed during short shutdowns of the RSSF. This storage basin will be provided in the CCF/RSSF design, and must be large enough to store 160 canisters of calcine.

In both cases, regardless of how the water basin storage facilities are provided, they must meet the following functional requirements.

- Maintain the waste in a safe condition at all times. including the duration and aftermath of all credible naturally occurring events. Class I construction is required. 
- Provide a safe heat sink which will allow adequate time to recover from loss of mechanical water circulation and heat removal.

- Provide containment within the system for radioactive material which might escape from the canisters, and also provide for the subsequent removal of such material in order to return the system to a safe and tolerable level of contamination and radiation.

- Provide radiation shielding sufficient to reduce occupational exposure of operating personnel to as low as practicable levels.

- Maintain water quality to prevent corrosion of the stainless steel canisters.

- Prevent the accidental lowering of the basin watex level more than 12 inches.

\subsubsection{Utilities}

In general the two concepts require the same type of utilities but capacities may vary. Both will be self-sufficient, except for some instances where the host facility may be able to supply a portion of the needs. Functionally, the requirements for both concepts are the same and the design of each utility system must satisfy all operating and safety demands under normal and accident conditions. Those utility systems or portions of systems which serve or support a class I function will be enclosed in Class I structures.

The following utilities will be supplied per Drawings $7238-100-P R-3$ and $7238-100-P F-3$.

- Water system for fire protection, demineralized water, potable water, soft water, cooling water, and emergency cooling water:

- Electrical system providing incoming utility power, emergency diesel-generated power, and emergency noninterruptible battery and inverter power:

- Compressed air system providing for both building and instrument uses as separate systems, and for process requirements:

- Building heat: 
- Fire protection, detection, annunciation, and quenching:

- Sanitary system:

- Fuel oil for diesel and other use:

- Aqueous makeup.

\subsubsection{Support Facilities}

Both of the CCF concepts require the same general support facilities, but they vary somewhat in detail.

4.1.4.1 Waste Treatment Facilities. All Iiquid and gaseous effluents from the process equipment, decontamination activities, and operations must be treated to reduce their radioactive constituents to levels permitted in section 3.10. The CCF/FRP will utilize the efiluent cleanup system of the host plant to accomplish this functional requirement, while the CCF/RSSF will provide its own cleanup systen.

Solid wastes generated by both facilities will be suitably packaged Eor storage at an approved site.

4.1.4.2 Ventilation. The ventilation system for all contaminated and potentially contaminated areas of the buildings shall be of the once-through type. Conditioned air will flow from the clean areas through the progressively higher contamination areas: the final exhaust air is passed through sufficient stages of IIEPA riltration to reduce the concentration of radioactive pariculates to levels permitted in section 3.0 . Monitors which both record and annuciace alarms shall be installed in the exhaust stack, upstream of the first stage of HEPA filtration, and at other selected locations.

The ventilation System shall be of Class I construction and be safely operable by the emergency power from the diesel generators. The systems are shom in Drawings 7238-100-HVR-4. $7238-100-$ HVR $-5,7238-100-$ HVT $-4,7238-100-$ HVF-5, and $7238-100-\mathrm{L}-\mathrm{T}$.

4.1.4.3 Radiological Protection and Instrumentation System. A11 variables important to safecy will be monitored over their minimum-maximum ranges, recorded, and annunciated in the control room when alarm set points are exceeded. The control room will have commuications equipment which can spread alams and direct corrective action. 
Specific functional requirements are:

- Detect radiation and airborne particulate radioactive material in all areas occupied by people, display the readings as dose rate or counts per minute as appropriate, and alarm when levels exceed pre-set limits.

- Detect radioactive material on the surfaces of objects and people.

- Detect radioactive material in all CCF effluents, and alarm this condition.

- Detect and alarm other conditions which affect safety, such as exhaust air system failure, instrument air system failure, low voltage, failure of the emergency power system, full liquid waste tanks, open air lock doors, fire, unauthorized intrusion, etc.

4.1.4.4 Maintenance and Administration. Both CCF's will be self-sufficient, regarding facilities and manpower, in performing their own routine maintenance and immediate administration. It is not intended, however, that the CCF's be equipped to perform major shop work, develop and mock up large equipment items, repair and calibrate intricate instrumentation systems, or stock large quantities of supplies and spare parts. For these types of services, and also for major administrative support, the CCF's will both depend upon the operations contractor at the site upon which they are located.

\subsection{CCF/RSSF CONCEPT}

\subsubsection{Functional Design Bases}

The specific functional design bases are given in section 3.0 .

\subsubsection{Facility and Equipment Arrangement}

The CCF/RSSF is a separate, self-sufficient facility located adjacent to the RSSF. A covered water canal will connect the CCF/RSSF and the RSSF. The CCF/RSSF building is a combination of reinforced concrete and insulated metal construction, and contains the hot cells for the conversion equipment and necessary support facilities. The building is shown in plan and section in Drawings 7238-100-AR-1 and 7238-100-AR-2.

The reference site is the Hanford reservation. 
Because of the nature and guantity of the radioactive material being handled and processed, all structures concerned with these activities are of Class I construction, as are those support systems which are vital to the protection of workers, the environment, and the general public.

\subsubsection{Operational Description}

After receipt at the RSSF, calcine canisters are unloaded from the shipping cask into an ISSF cell, visually examined, and a smear is taken. If acceptable for further transport and receipt at the CCF, the canisters are cooled, placed into a water canal and moved to the CCF. The canisters may either be temporarily stored in the 12 storage pool or transferred directly into the decanning and conversion cell.

In the decanning and conversion cell the canister is opened and a valved adaptor is installed in place of the removed lid. The canister is then inverted and connected to the crusher. Mild vibration is applied to empty the contents into the crusher. After agglomerates have been crushed, the calcine is transferred to a blender. There it is blended with glassmaking frit in the proper proportions.

The previously emptied canister is transferred into the incanister glass-making furnace and connected to the blender. Blend is fed into the canister. As melting proceeds more blend is added until the canister is filled to the correct level with glass.

The molten glass is slowly cooled, to reduce cracking, until it is cool enough for a dr transfer. The canister is disconnected from the blender, the final lid mechanically installed, and the canister transferred to the product quality assurance cell. Because of the slow cooling step. six furnaces are provided to assure an average production rate of 2 canisters per day.

The closure weld is made and leak tested. The canister is then cooled to the point where water decontamination will not significantly thermally shock the canister or the glass, and the canister surface is decontaminated to levels acceptable to the RSSF. The canister of glass is then placed in the transfer canal and transported back to the RSSF where it is processed for storage.

More detailed descriptions of the important operating steps follow. 
4.2.3.1 Receiving. Canisters of calcine are received at the RSSF From the fuel reprocessing plants. Following inspection for physical integrity and smearable surface contamination, the canisters are cooled to a point approved. for water immersion.

4.2.3.2 Transfer. The cooled canisters are transferred to the CCF/RSSF via a covered water canal which is provided with a suitable conveying system. The concrete canal is lined with stainless steel, and is the same depth as the lag storage pool with which it connects. Water quality and contamination level are maintained by the same equipment which performs these functions for the lag storage pool.

At the opposite end of the storage pool the conveyor continues through a short length of canal, terminating underneath the decanning and conversion cell, where the in-cell crane can pick up the cansiter.

4.2.3.3 Storage. If a canister is to be stored instead of going directly into the process, the conveyor will stop in the lag storage pool. The overhead crane servicing the pool will then remove the canister and place it into a selected storage position. The concrete pool is lined with stainless steel to reduce leakage and permit monitoring for leaks. This lining also aids in preserving water purity. An ion exchange system is provided to remove radioactive material from the water and to maintain the purity of the water. The pool contains storage cacks for canisters, which are so designed that any selected canister can easily be retrieved by the overhead crane and placed on the conveyor.

4.2.3.4 Decanning. Upon receipt in the decanning-conversion cell, the canister is placed in the decanner. This equipment is designed to cut out the seal weld at the top of the canister and remove the 1id. It will also be able to cut off the entire top of the canister if necessary.

When the Iid has been removed, an adaptor lid is installed which contains a large valve. The canister is then turned upside down and the adaptor engaged with the crusher.

4.2.3.5 Crushing. The valve is opened, and the calcine flows into the crusher with the aid of mild vibration of the canister.

In case some of the calcine has agglomerated into lumps or clinkers, a crusher is required to reduce all calcine particles to allow transport and adequate mixing with glass formers. 
4.2.3.6 Blending. The calcine is fed into blenders where it is mixed with the appropriate quantity and type of glassmaking Erit.

4.2.3.7 Melting. A distribution system feeds blend to any of six furnace-coolers into which are placed empty, used calcine canisters with Iid adaptors to connect to the distribution pipes. Blend is fed into a canister, and as the bottom portion melts more blend is added until the level of molten glass reaches the desired height. The melt is then furnace cooled slowly until the glass is at equilibrium temperature.

4.2.3.8 Welding. The canister of glass is then removed to the product quality assurance cell where a new lid is welded in place. At least initially, the canister will then be overpacked in a new canister.

A selected few of the old, used calcine canisters will be destructively examined at some appropriate hot lab facility in order to determine whether or not they could be approved as primary containment for glass. If used canisters can be approved, then the expensive step of overpacking could be eliminated.

The final closure weld will be helium leak-checked.

4.2.3.9 Decontamination. Two methods of canister decontamination will be provided; high pressure water sprays and ultrasonic cleaning baths. These methods will be repeated, if necessary, until smear survey shows the canister to be clean enough to be transferred to the RSSF.

\subsubsection{Maintenance and Repair}

All of the in-cell equipment will be designed for remote maintenance and repair and also for remote replacement. selected spares will be kept in stock.

When maintenance and repair work cannot be successfully performed in place, the equipment item will be disconnected, decontaminated as much as possible, and transferred to the maintenance cell with the canyon crane. If it cannot be successfully repaired there, it will be removed into a shielded burial box and loaded onto a truck in the truck airlock. Replacement equipment wil follow the reverse path into the process ce11. 
All other maintenance and repair work, including what is required for manipulators, will be done by contact. Manipulator work will be done in a special shop which is partitioned into a warm and cold area.

\subsubsection{Sample Analysis}

At various stages in the process, samples of blend and product are taken as control and $Q A$ measures. These samples are pneumatically transferred to the analytical cell where they are examined. Some samples will be stored as archive samples.

\subsection{CCF/ERP CONCEPT}

The CCF/FRP is very similar to the CCF/RSSF in that both facilities will be designed to convert calcine to glass to make it more satisfactory for long-term storage in the RSSF. Both facilities will consist of a series of remote process cells containing equipment to melt the frit/calcine mixture and seal it in high quality canisters.

The following sections will describe the significant details of the CCF/PRP

\subsubsection{Functional Design Bases}

Specific functional design bases are given in section 3.0 .

\subsubsection{Facility and Equipment Arrangement}

The CCF/FRP is housed in a reinforced concrete structure adjacent to the FRP and is shown on Drawings 7238-100-AF-1 and 7238-100-AF-2. Two processing cells are provided, one for blending and melting the frit/calcine and the other for sealing the canisters and performing $Q A$ operations. These cells are supplemented by an analytical cell and a hot maintenance cell. The cells are arranged in a single line and are covered by a shielded canyon equipped with a crane that can move equipment from cell to cell for maintenance purposes after removal of cell cover blocks.

The operating gallery is on the front of the line of cells. It is equipped with viewing windows to observe cell operations and with master-slave manipulators to aid maintenance. Each cell has an in-cell bridge crane to handle canisters of glass and assist with maintenance operations. 
A service gallery abutts the back of the cells and is used for bringing services to and from the cell spaces. No viewing windows are provided between the cells and the service gallery.

A drain system and ventilation ducts are in the space below the cells.

Spaces for personnel, utilities, control rooms, etc., are provided at appropriate locations outboard of the service and operating gallexies.

\subsubsection{Operational Description}

The calcine is received as a continuous stream from a calciner located in the FRP. The calcine is mixed with a predetermined amount of glass frit in a rotating blender. The blend is periodically sampled and analyzed before being dumped into a new stainless steel canister in a melter/cooler unit. At about $1,000^{\circ} \mathrm{C}$ the blend will melt and slump in the canister making it necessary to add more blend to fill the canister. After one or two supplemental fillings, the canister will be 80-90 percent full of glass and will be ready for the cooling phase of the cycle. Cooling will be at a controlled rate to avoid temperature shocks to the glass monolith. After the glass is properly cooled, the cover is welded to the canister and the assembly is tested to be sure it meets the process standards.

The decay heat of a representative canister of glass 1 foot in diameter by 15 feet high is about 50 kilowats, which will reheat the canister of glass at about $3^{\circ} \mathrm{C}$ per minute if no heat is removed. This makes it necessary to keep the canisters of glass in cooled stations except for brief periods in air during transfer from station-to-station. When all processing operations are completed the canisters of waste are placed in a water basin for a period of several years until the decay heat reduces to 5-13 kw per canister and the canister of waste can be shipped to the RSSF for long-term storage.

Canisters used for product glass from the CCF/FRP are new and of very high quality. They enter the calcine conversion cell from the canyon area via shielded air locks and are moved by an in-cell crane to one of the melters.

After being filled with the waste/frit mixture, which is then melted and solidified, the canister of glass is moved by the in-cell crane to the decontamination station or directly to 
the intercell transfer system. This system moves the canister of glass through an air lock in the cell wall to the oA cell where it is picked up by an in-cell crane and placed in the canister welding mechanism.

The QA cell crane moves the canister from station-to-station in the QA cell and finally places it in an arm of the water storage basin that extends into the gA cell. From this point the canister of glass is transported under water in canals that connect to the water storage basins.

\subsubsection{Maintenance and Repair}

The environment within the process cells will be highly radioactive from materials inside the equipment or firmly attached to surfaces making it impractical to clean the cells for personnel entry. Maintenance of equipment within cells will be performed in the following manners.

- All possible cell auxiliary or control equipment will be installed outside the cells to permit contact maintenance.

- Items of low contamination level may be located in service gallery niches or small compartments which can be decontaminated and opened for contact maintenance.

- Minor maintenance and adjustment of in-cell equipment will be performed by master-slave manipulators and incell bridge cranes. Tools and replacement parts for such maintenance will enter and leave via pass-through openings or through canister passageways.

- Maintenance jobs beyond the capability of the in-cell equipment wil require the use of the remote canyon crane after removal of cell cover blocks. Extensive decontamination of cell interiors will be required before removal of cover blocks. The maintenance operations to be performed in this category will normally consist of remote removal and replacement of large components without attempting to make immediate repair of components.

- Failed equipment remotely removed from process cells will be transported by canyon crane to the maintenance cell for further decontamination prior to repair or disposal.

\subsubsection{Waste Disposa1}

The operation of the conversion equipment and its auxiliaries will release small amounts of calcine to the cells. This 
calcine must be collected and stored. The interactions of this collection and storage system with other parts of the CCF and the FRP is quite complex and only the bare essentials are covered below.

4.3.5.1 Solid Waste Materials. Occasional leakage or spills of waste in process are expected to occur. Such matexial will be retrieved and returned to the process wherever possible by use of vacuum cleaners, etc. Materials not returned directly to the process may become airborne or may fall to the cell floor. Waste which stays airborne for a few minutes will be picked up by cell exhaust filters; waste which falls to the floor (or settles on equipment) may be removed by vacuum cleaning or by water flushing during occasional cell decontamination efforts.

Contaminated filters will join items of failed cell process equipment and tools for packaging and disposal with FRP solid wastes.

4.3.5.2 Iiquid Waste Erfluents. Water that has been used for flushing, or has become contaminated by any means, will be collected in a cell drainage system and sent to the FRP for treatment by evaporation and/or ion exchange.

4.3.5.3 Gaseous Effluents. The melting process will release radioactive gaseous materials due to the high temperatures reached in the melting process. This system, as well as other process equipment and piping containing loose calcine, will be treated as a process off-gas system operated under a slight negative pressure to make sure all leakage is inward. The discharge from the process off-gas system will be returned to the FRP for treatment in the FRP off-gas system.

4.3.5.4 Cell Exhaust Air. Air will be circulated through the process cells to provide cooling and to maintain airflow in the proper direction. Such air will pick up loose contamination which must be removed before release to the environs. This is accomplished by multiple HEPA filters in series, the first filter in each series being within the process cell where it can be removed remotely and treated as solid waste (see 4.3.5.1). Subsequent filters will be an exterior fanfilter facility. The system is illustrated in Drawings 7238-100-HVF-4, 7238-100-HVF-5, and 7238-100-I-7. 


\subsection{TECHNICAL ANALYSES}

\subsection{WASTE CHARACTERISTICS}

The high level waste calcines arriving at the CCF for conversion to glass may vary widely in their physical, chemical, and radiation characteristics. Differences in fuel type, reprocessing flowsheets, and calcination procedures will be contributors to these variations. Time from reactor discharge has a major effect on the thermal and radiation properties of nuclear wastes.

Calcines are formed by thermal treatment of aqueous waste solutions to form dry solids which are principally oxides of the various waste constituents. Alkali metals, whose oxides are relatively unstable, are a partial exception. In waste containing significant alkali metal concentrations it will probably be necessary to convert the alkali metals and nitrates to compounds more stable than simple oxides before shipment to the CCF or RSSF.

Shipments to the CCF through the year 1990 will result predominantly from LWR-U processing, which is the reference design. Projections indicate a small amount of $\mathrm{PWR}-\mathrm{Pu}$ and HTGR waste may also have reached the 10 CFR 50 age 1 imit of 10 years by 1990. It should therefore be possible to accommodate smaIl amounts of these wastes in the CCF by flowsheet adjustments or other techniques.

Certain assumptions are made concerning other characteristics of the waste.

- Stability

The dry solid is chemically, thermally, and radiolytically stable to the extent that (1) the equilibrium pressure in the sealed canister will not exceed the safe operating pressure for the canister during the period from canning through a minimum of 90 days after receipt at the CCF. and (2) corrosion of the canister material will not decrease the requixed design strength of the canister.

- Decay Heat

The radioactive heat generation of each reference design canister (12.75" OD $x 1^{\prime \prime} 5^{\prime}$ long) will not exceed $13 \mathrm{kilo-}$ watts at the time it leaves the CCF for storage at the RSSF。 
- Physical Form

Ideally, the waste calcine will be a free-flowing, homogeneous powder with a well characterized uniform particle size. Alternatively, the waste calcine may be loosely consolidated. In all events, it should be amenable to draining from the canister upon receipt at the CCF/RSSF, with no more than mild external impacting of the canister walls being required to expedite the removal.

\subsection{PLANT CAPACITY AND AGE OF WASTE}

\section{$5.2 .1 \mathrm{CCF} / \mathrm{RSSF}$}

The CCF/RSSF will be designed to convert, on a routine basis, the calcine generated by the reprocessing of 8 tonnes of uranium fuel per day (2,400 tonnes per year) as young as five years out of the reactor.

5.2.1.I Discussion of Plant Capacity. The bases for developing the capacity of the CCF/RSSF are the modified predictions of reprocessing loads and startup dates contained in ORNL-TM-4631. August 1974, J. O. Blomeke, C.W. Kee and R. Salmon, "Projected Shipments of special Nuclear Material and Wastes by the Nucleax Power Industry." These projections were modified by ARHCO to reflect recent known changes in startup dates and waste solidification plans for the FRP's. Figure 5-1 shows these projections as the accumulated backlog of calcine filled canisters (1' in diameter $x 1^{\prime}$ long). and shows the effect on this backlog when the CCF/RSSF goes into operation in January 1983, with the capacity to convert the calcine produced from reprocessing 8 MTU per day.

It appears reasonable that the fuel reprocessors will have the capability to incorporate their calcine into glass by 1990: thus, no additional calcine filled canisters will be generated beyond that date. The CCF/RSSF can work off the backlog of 5,300 canisters, at the rate of 600 per year, by the year 1999. This would appear to be a reasonable plant lifetime of less than 20 years.

With this capacity to convert the calcine resulting from reprocessing 8 MTU per day, the CCF/RSSF can adequately demonstrate the calcine conversion process and the capacity will closely approach that which is forecast for future fuel reprocessing plants. 


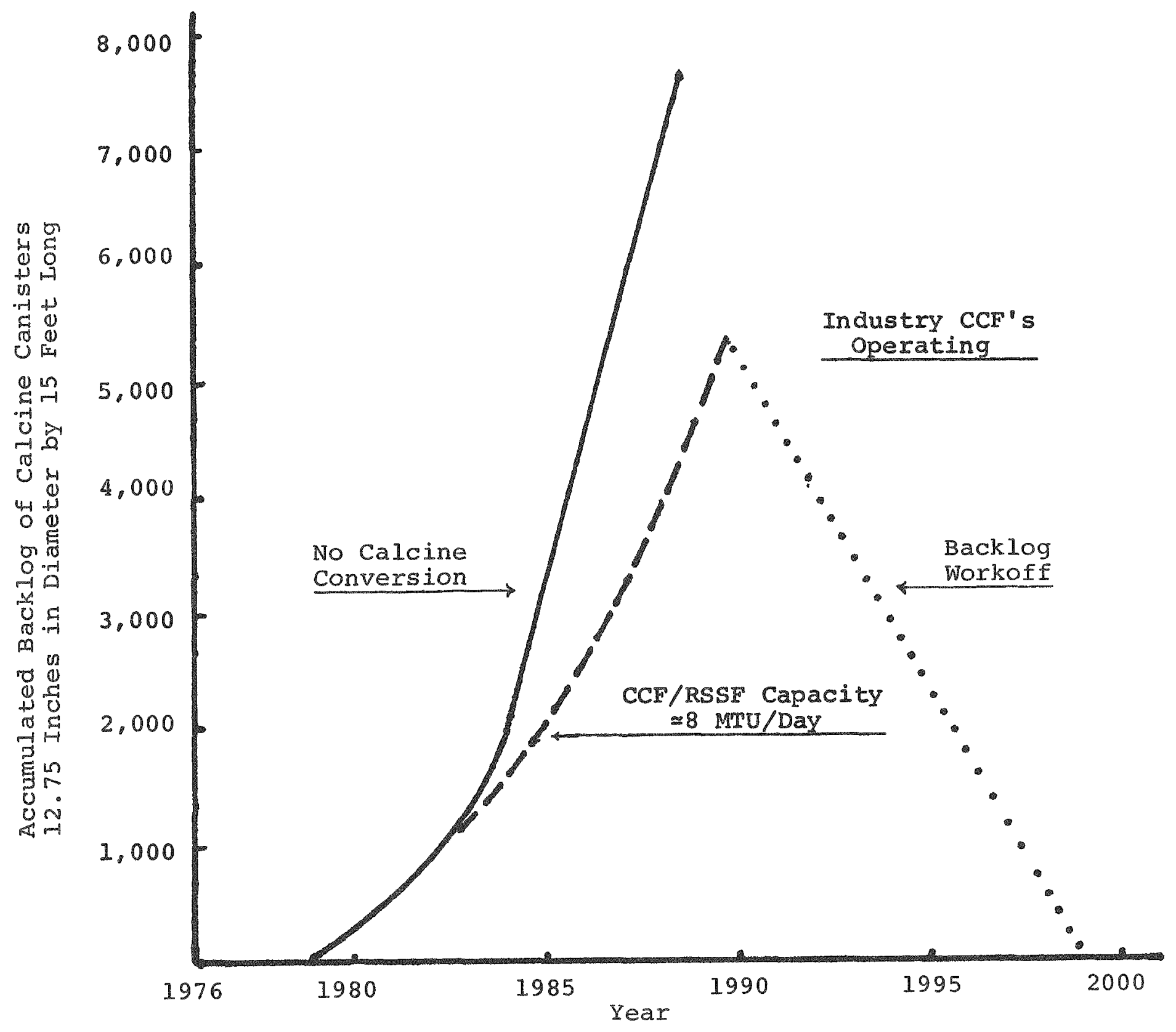

FIGURE $5-1$

CALCINE CANISTER ACCUMULATED BACKLOG AND CCF/RSSF WORKOFF 
However, since this CCF/RSSF capacity will produce a backlog of approximately 5,300 cansiters by 1990, storage of the backlog will be a significant problem. Reducing this backlog could be accomplished by (1) increasing the capacity of the CCE/RSSF after the first few years of operation, (2) building a second CCF/RSSF, or (3) shortening the time when industry CCF's can be on-line. It does not appear practical at this time, from a material handing and technology standpoint, to increase the capacity of the fixst CCF to demonstrate the calcine conversion process beyond two canisters per day (waste equivalent to $8 \mathrm{MTU} / \mathrm{day}$.

5.2.1.2 Discussion of Age of Waste. The bases for establishing the normal age of calcine to be converted at the CCF/RSSF are also the predictions of ORNI-TM-4631. From the calculated heat loads at various ages, and the practicalities of shipping cask size, weight, and heat removal systems, it appears that five-year-old waste would be the youngest waste which is practical to ship. This age is therefore the design base for the CCF/RSSF normal operation, and is used for shielding calculations, heat removal within the process equipment system, cell heat loads, etc.

For demonstration purposes, it might well be desirable to convert three-year-old waste on a one-time or occasional basis. The batch used would be smaller and perhaps some equipment alterations would be necessary: but, such a demonstration would be feasible. The data from this demonstration could be extrapolatable to six-month-old waste, although it is not considered reasonable to attempt an actual demonstration. This is primarily because the effluent cleanup system probably would not be able to safely contain the shorter-lived effluents.

\section{$5.2 .2 \mathrm{CCF} / \mathrm{FP}$}

The CCF/FRP will be designed to convert the waste from 5 tonnes of uranium fuel per day (1,500 tonnes per year) as young as one year out of the reactor. Limited amounts of fuel as young as six months out of the reactor will also be converted under special conditions.

It must also be possible to extrapolate the data from the special testing to the design of a facility that can convert waste six months out of the reactor as a routine full-scale operation. 
5.2.2.1 Discussion of Plant Capacity. The CCF/FRP is to become an annex to a fuel reprocessing plant with the prime purpose of converting the calcine fxom that FRP to a glass product suitable for storage in the RSSF. It would appear, therefore, that the CCF capacity should be identical to that of the FRP that it serves. Since current conceptual plans call for the CCF/FRP to be adjacent to the 5 tonnes of uranium fuel per day Allied General Nuclear services, it should have the capacity for processing the waste from that amount of fuel. Factors tending to contradict such a decision include the following:

\section{- Backlog Disposal}

The CCF may not get started as soon as the FRP, and the FRP may be producing calcine which will be stored in the FRP basin until it can be converted in the CCF. In the case being considered, the tentative startup date for AGNS calcine production is 1979, and the tentative startup date for the CCF is 1983. Allied General Nuclear Services will have storage space for one year's waste production as a liquid, leaving three years" waste at 1,500 tonnes/ year, which will backlog as a calcine. The calcine from 4,500 tonnes would fi11 about 1,000 standard canisters 12.75 inches in diameter by 15 feet long.

The above is believed to be the worst backlog condition. This amount of backlog might prove difficult to handle in a reasonable length of time. However, a delay in AGNS startup or a failure to negotiate a working agreement between the ERDA and AGNS would modify the above hypothesis. The decision to design the CCF for 5 tonnes per day capacity must be re-examined in the light of later developments.

Another factor to be considered is the possible shipment of the calcine generated prior to the availability of the CCF to the RSSF. Such material could be stored in the RSSF as a calcine, or returned to the CCF at a later date, to be converted to a glass form.

- Calcine From Another FRP

It might be worthwhile to provide extra capacity at a single CCF/FRP to permit it to convert calcine from other FRP's, thereby reducing the number of CCF's required by industry. This idea was abandoned because 
the resulting Eacility would become very similar to the CCF/RSSF and could best be accomplished by changing the site of the CCF/RSSF to the vicinity of an FRP.

- Pilot Plant at an FRP

Another alternative would be to design a small-capacity pilot plant adjacent to an FRP. This arrangement would permit process demonstration without regard to throughput rates. Ilowever, this approach would delay the availability of a full-scale CCF, and the backlog of calcine would be substantial.

5.2.2.2 Discussion of Age of Waste. A basic requirement for an FRP handing fuel from early light-water reactors is that the fuel must be about six months out of the reactor before being reprocessed. This permits decay of short-life fission products. The high level waste from the fuel may be either converted immediately to calcine (as planned by General Electric) or stored as a liquid for as long as five years, as permitted by $10 \mathrm{CFR}$ 50, Appendix F. Current plans at AGNS provide a liquid storage averaging about six months, for a total time out of reactor of one year.

The age of waste will have a substantial effect on the CCF design because of the higher heat loads and higher radiation intensity. One-year-old waste was selected as the nominal design age for the first CCF/FRP since that is believed to be the minimum age of waste that will be processed through the AGNS facility under normal conditions. However, in recognition of the fact that AGNS may decide to eliminate the liquid storage step, or that other $\mathbb{F R P}^{\prime} \mathrm{s}$ may be designed without any liguid storage, the CCF/FRP will be designed to handle six-month-old waste on a demonstration basis.

The essential differences between CCF's for young waste and those for older waste are (1) younger waste generates more heat requiring special equipmenc designs to prevent overheating: (2) younger waste releases more radioactive off-gas: and (3) younger waste has higher radiation levels, which will require additional personnel shielding and will shorten the life of organic materials. thereby requiring additional maintenance. 


\subsection{WASTE ACCEPTANCE CRITERIA}

The CCF/RSSF shall be designed and equipped to accept the same calcine that is acceptable to the RSSF. The criteria are in the process of being developed.

The CCF/FRP shall be designed and equipped to convert whatever calcine is produced by its host plant.

\subsection{SITE DESCRIPTION}

Formal selection of a site for the RSSF and CCF/RSSF has not yet been announced by the ERDA. However, a reference site located at the ERDA's Hanford reservation has been selected for use in those aspects of the conceptual design which require specific site information. The conceptual design is intended to represent a facility which could be located at any government-owned site in the united states at which certain minimum required site characteristics are met. It is believed that the Hanford reference site features are sufficiently typical of other potential sites to facilitate reevaluation and modification of site-related design features when the selected site is announced.

\section{4 .1 Location}

The reference site is located within the ERDA's Hanford reservation in the southeastern part of the state of Washington, as shown in Figure 5-2. The Hanford reservation has served as a nuclear centex since 1943, and has not been opened to the public since its inception.

The specific reference site lies on a plateau near the geographical center of the reservation, near the 200 West Area, as shown in Figure 5-3. The site area available is about 2,000 acres of which about 1,100 acres would be needed for the RSSF and a CCF. This area includes section 35 and portions of Sections 31 and 36 of Township 13 North, Range 26 East. The plot plan is shown in Drawing 7238-100-CR-6.

The reference site for the CCF/FRP is the Allied General Nuclear services Plant, whose site information is published in their Final Safety Analyses Report Docket No. 50-332. The plot plan is shown on Drawing 7238-100-CF-6.

The detailed characteristics of the Hanford site are reported in WASH-1539 (Draft). "Environmental Statement, Management of Commercial High Level and Transuranium-Contaminated Radioactive Waste," September 1974. 


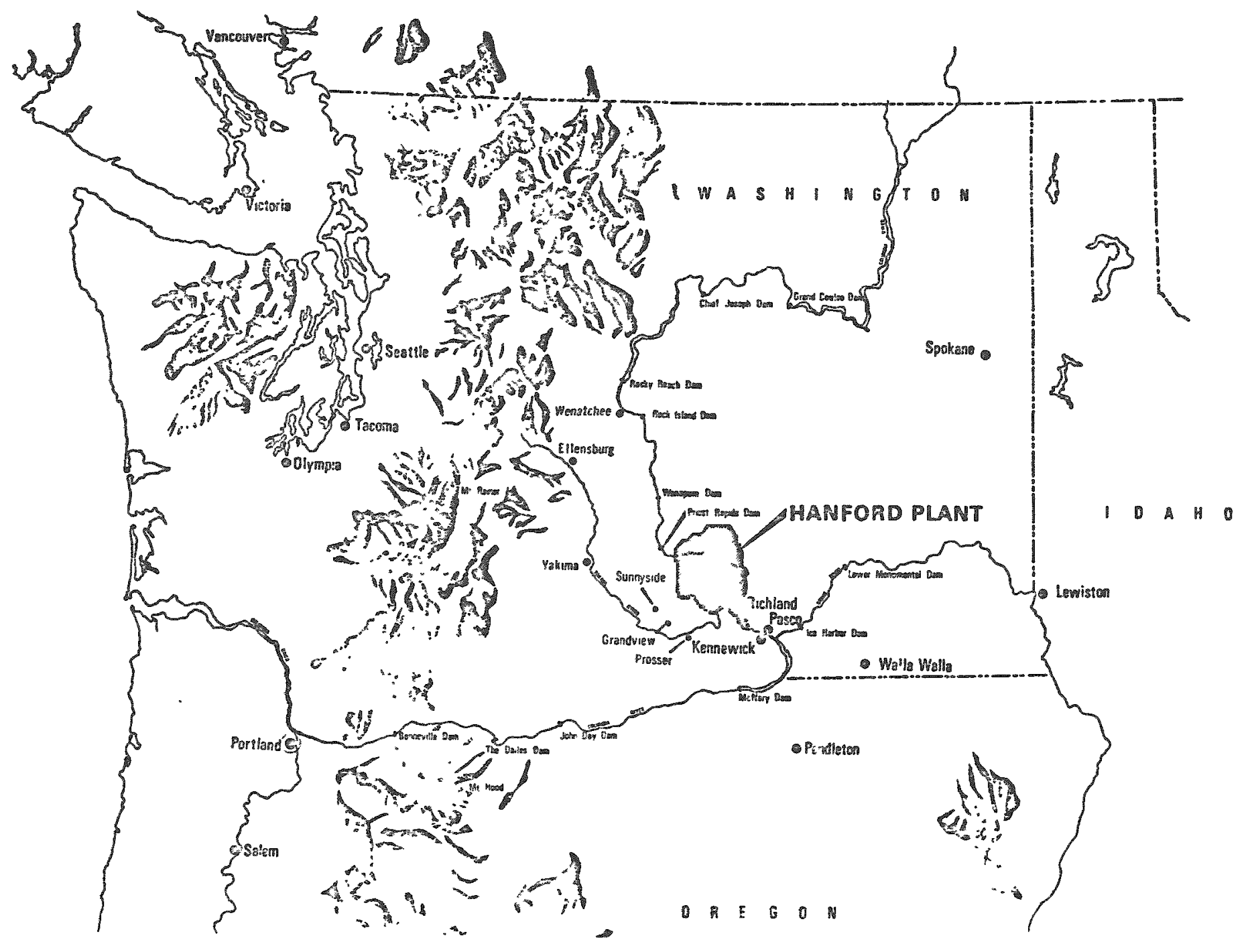

$\omega$

FIGURE $5-2$ 


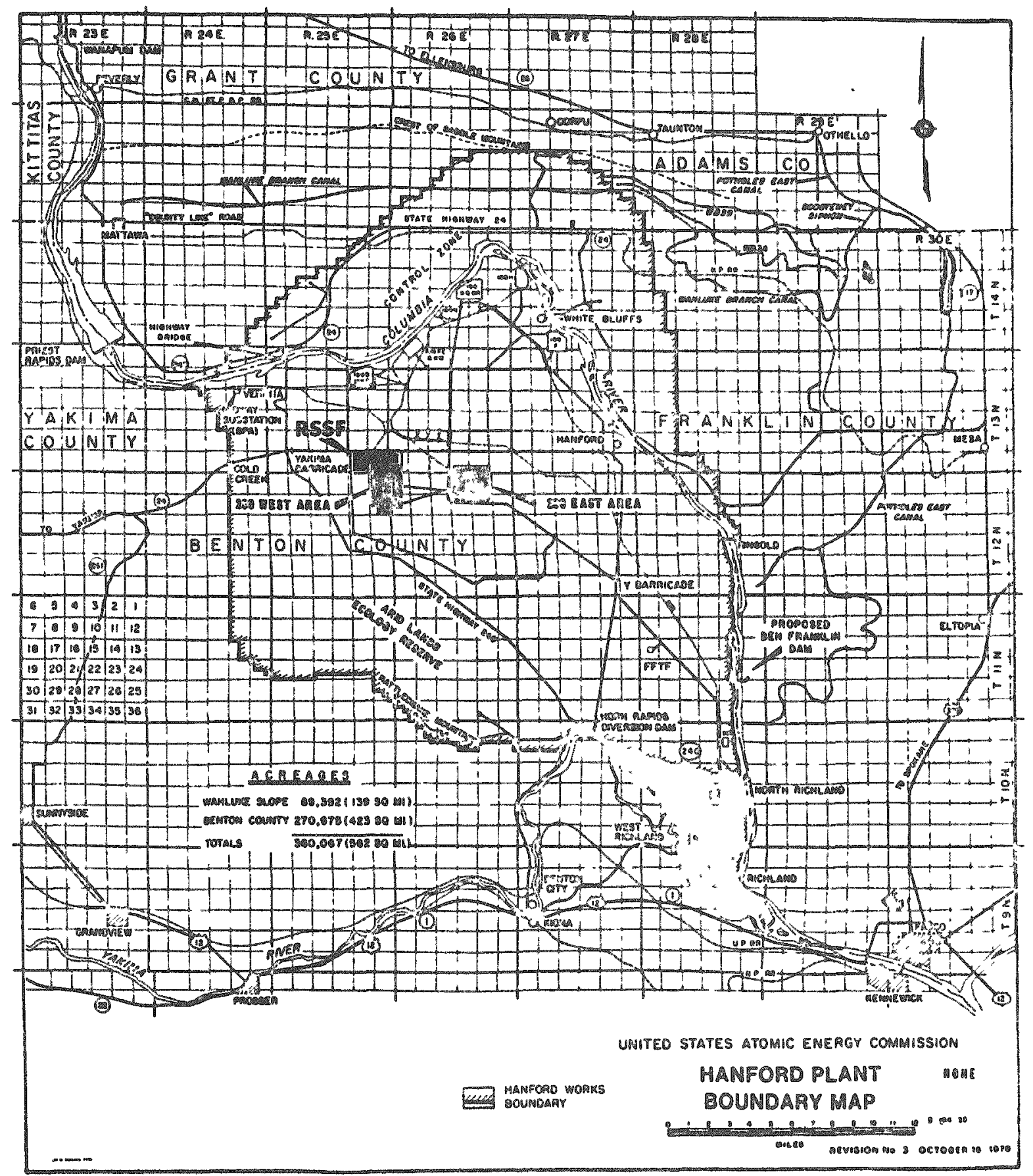

FIGURE $5-3$

MAP OF HANFORD AEC RESERVATION 


\subsection{SHIELDING}

For the purposes of this comparison study, the cell wall shielding provided ( $6 \mathrm{ft}$ of ordinary concrete or $4 \mathrm{ft}$ of high density concrete) for both concepts is the same. After one concept is selected for continuing conceptual design work, a more sophisticated shielding analysis will be made.

\subsection{GLASS CHARACTERISTICS}

Glass formed in the CCF will be a silicate with additions of zinc, boron, alkali and alkaline earths, and/or lead. The glass will be formulated to achieve a highly nonleachable product containing 20-35 weight percent calcine. The fission products and actinides in the calcine become part of the glass matrix, thereby greatly reducing their potential for dispersion into the biosphere.

Glass has tremendous strength in compression, but can be cracked by rapid cooling. The severity of cracking is a direct function of the cooling rate. The thermal conductivity of high level waste glass is about 0.8 watts $/ \mathrm{m}^{2} /{ }^{\circ} \mathrm{C} / \mathrm{m}$ at room temperature and increases as much as a factor of 4-10 between room temperature and $1,000^{\circ} \mathrm{C}$. The glass has a density of over $3.2 \mathrm{~g} / \mathrm{cc}$ and does not contain open porosity.

While the quantity of glass produced will be a function of the chemical composition of the calcine, a relatively pure calcine can be expected to have a glass volume of about 1.4 cubic feet per tonne of fuel reprocessed. The total volume of waste will increase due to addition of glass frit and an average value of 2 cubic feet per tonne of fuel has been assumed as a basis for conceptual design.

Criteria for the glass product are still under development. 


\subsection{SAFETY ANALYSIS}

\subsection{INTRODUCTION}

This analysis presents the safety considerations which pertain to the planned CCF. whose function is to convert calcine into a glass material on a demonstration plant scale.

The primary advantages to be attained by incorporation of calcine into glass are more favorable leachability and dispersibility characteristics, resulting in reduced risk of accidental waste transport into the surrounding environment. Waste leachability in water would be reduced by a factor of about 100,000 and dispersibility would be reduced by virtue of the particle size ranges being measurable in inches, rather that in millimeters or microns. The monolithic glass form also provides about a factor of four improvement in heat transfer characteristics (i.e., increase in bulk thermal conductivity) over the calcine form.

The safety analyses which have been performed at the current state of CCF design development are preliminary due to the preliminary design status. Additional and more detailed safety analyses will be required as the design work progresses. Safety analysis topics requiring aditional process or facility definition are identified in these preliminary analyses.

The purpose of these preliminary analyses, developed in conjunction with the facility preliminary design, is to evaluate engineered features which prevent or mitigate potentially unacceptable safety hazards and to identify areas requiring further design development and safety analysis. The conditions and accidents which the facility will be designed to accommodate and control range from those common in all industrial glass production facilities to those specific to plants in which radioactive materials are handled and stored. The safety considerations described in this section are primarily those having potential for loss of radioactive material confinement and/or having the capability of exposing either operating personnel or the general public to a radiation dose in excess of acceptable limits. It is assumed that other types of industrial accidents (e.g. motor vehicle collisions, electrical shock, burns, falling, etc.) are amenable to resolution by standard design practices, administrative control. and industrial safety procedures. 
The main steps in the processing of calcine through the CCF where accidents could most probably occur are as follows:

- Receipt of canisters containing calcine from the RSSF

- Optional lag storage of calcine canisters in a water basin

- Removal of calcine from canisters

- Transport and particle size reduction of calcine

- Transport of crushed calcine and blending with glass frit

- Melting, casting, and annealing to form the glass product

- Inspection, sealing, and testing of glass product canisters

- Transfer of glass product canisters to the RSSF.

The CCF would be either an addition to, or an integral portion of another facility. Therefore, these safety analyses have been directed primarily toward safety considerations which are specific to the incorporation of calcine into a glass material. other specific safety considerations which are identical or similar to those encountered in the other facilities are treated in only a cursory fashion in these safety analyses.

Since the CCF would be built and operated in conjunction with another facility, there would be some safety-related general design philosophies, structural requirements, and administrative policies which would be applicable to both facilities as a whole. Therefore, these items, as they apply to the CCF, are included in this safety evaluation to insure a more complete presentation.

Three categoxies of operating conditions and accidents have been considered in the safety analyses: (1) normal operations, (2) abnormal operations, and (3) improbable events. This categorization is based on a qualitative evaluation of probability (or frequency) of occurrence and severity of release consequences, as compared to applicable maximum radionuclide concentration and/or radiation dose limits. Further definition of these operating and accident categories is provided in the following paragraphs. 


\subsection{NORMAL OPERATING CONDITIONS}

Radioactive material releases during normal operating conditions involve very small quantities of radioactive materials released during routine planned operating conditions. Normal operations include some anticipated equipment or process failures that require deviation from routine procedures, but do not include those failures which result in lengthy shutdown time or which cause a radioactive material release from its normal confinement.

During normal operations, the radiation exposures to the general public and the radionuclide concentrations in plant liquid and gaseous effluents shall be in accordance with the ERDA's policy of maintaining releases as low as practicable. In any event, these exposures and concentrations will be no greater than 10 percent (arbitrarily determined design philosophy value) of the maximum limits presented in $10 \mathrm{CFR} 20$.

\subsection{ABNORMAL OPERATING CONDITIONS}

The CCF will incorporate design features which mitigate the consequences of postulated abnormal operating conditions and which facilitate safe recovery from such situations. The conditions considered in these safety analyses include those that might result from major equipment failures, operator errors, or unplanned process variations which may occur sometime during the plant operating life. Some of these abnormal conditions are expected to result in minor contamination spread; however, such contamination will be predominantly confined to operating areas and recovered. In any case, abnormal operation shall not result in radiation exposure to operating personnel or to the general public in excess of the limits presented in $10 \mathrm{CFR} 20$. Furthermore, the result of abnormal operating conditions, in terms of average radionuclide concentrations, both within and beyond the site boundary, shall not exceed the limits.

Certain abnormal operations create a potential for radiation exposure to operating personnel, radioactive material released (in liquid or gaseous effluents). or inadequate removal of radioactive decay heat. Therefore, the concrete shielding used for CCF hot cells will be designed for continued effectiveness during and after credible abnormal and accident occurrences. Confinement barriers to an atmospheric discharge of radioactive waste are provided by the building structures off-gas treatment system, and ventilation exhaust filtration systems. The normal ventilation air path in the facility will 
be from areas of low contamination potential to areas of higher contamination potential. Exhaust air from contaminated areas will pass through at least two sets of HEPA filters, in series, prior to discharge. The facility design is such that inadequate removal of radioactive decay heat will be an infrequent problem. Prompt recovery methods and procedures will be available for use, even under accident conditions to restore adequate waste cooling before high temperatures could threaten waste confinement.

\subsection{IMPROBABLE EVENTS}

The safety evaluation includes analyses of highly improbable accident conditions which are not expected to occur during the operating life of the facility: however, design features which further reduce the probability and possible magnitude of waste confinement loss, which could result from these events, are justified by the potential consequences. The improbable events category includes not only credible occurrences but also some events which are considered to be increaible due either to their natural low probability of occurrence or to their prevention by facility siting or design and administrative controls.

If an improbable event occurs, plant effluent radionuclide concentrations or radiation exposure to the general public could conceivably esceed limits. However, design philosophy dictates that the maximum credible accident (in terms of quantity released) shall not result in radiation exposure to any member of the general public which corresponds to greater than 2.5 rem whole body $(10$ percent of the 25 rem whole body exposure guideline presented in 10 CFR 100, entitled, "Reactor Site Criteria").

The CCF cells and associated off-gas treatment and ventilation exhaust air filtration systems will be designed as Class I confinement barriers capable of withstanding design basis accident conditions. The methods of preventing loss of waste confinement due to the potential occurrence of improbable events are based upon the same basic design philosophies as those used in the RSSF conceptual design.

\subsection{ATMOSPHERIC DISCHARGES}

The presence of low level radioactive contamination in most portions of the CCF, and the formation of very small amounts of induced activity where high level waste neutron fluxes are present, will result in slight but essentially continuous 
radioactive discharges to the atmosphere. These discharges will be minimized by the use of at least two sets (in series) of HEPA filters on the ventilation exhaust air from potentially contaminated areas and, to some extent, by ventilation air flow control. Routine "housekeeping" procedures will minimize the amount of contamination available for resuspension in ventilation air. In any case, the normal gaseous effluent dispersion and dilution will result in concentrations at the site boundary which are far below the nonoccupational limits.

\subsection{LIQUID WASTES}

Liquid decontamination agents will be used in the cleanup of contaminated plant areas, equipment, and waste canisters. The spent decontamination solutions, and other liquid wastes that may be contaminated, will be held in a suspect waste tank while labatory analyses are being performed. If these analyses show that an "as low as practicable" criterion is satisfied, the wastes will be transferred to a surface disposal pond. Wastes for which surface disposal is not acceptable will be routed to the waste treatment system for concentration and recalcination. The resulting calcine will be blended with incoming calcine for incorporation into a glass material.

\subsection{SOLID WASTES}

Operation of the CCF will generate low level contaminated solid waste which will be stored within the CCF. This waste, unlike the high level radioactive waste, results primarily from the occasional decontamination work which must be done in the facility. It consists primarily of disposable clothing, rags, paper products, laboratory chemicals, and ion exchange resins. Final storage of this low level solid waste material, in appropriately designed packages, will be performed at an approved ERDA or commercial disposal site. 


\subsection{ENVIRONMENTAL ASSESSMENT}

No environmental assessment has been made of the impact of constructing and operating a CCF, since neither a concept nor a site has yet been chosen.

However, potential sites for the RSSF have been assessed in WASH-1539, "Environmental statement: Management of Commercial High-Level and Transuranium-Contaminated Radioactive Waste," September 1974; and sites of FRP"s which might host a CCF/FRP have been individually assessed in their own environmental statements.

When a CCF concept and site are chosen, a specific environmental assessment will be made prior to the request for budget approval. 
ARII-LD- 108

\subsection{CAPITAL COST ESTIMATES AIND CONSTRUCTION SCHEDULES}

\subsection{CAPITAL COST}

The capital costs given in this section are based on preliminary engineering studies, without full design integration with the basic facility to which the CCF will be attached. Design studies and cost estimates for the CCF/RSSF are more complete because of an earlier starting date for the study. Also, both the RSSF and CCF are new facilities being designed by the same parties. In the case of the CCF/FRP, it was necessary to make unilateral interface assumptions which may not be accepted by the FRP management when the FRP is finally selected. However, in both cases an attempt has been made to equitably divide the cost between the CCF and the basic RSSF or FRP.

The capital costs given in this section cover only the costs of the facilities described in this report. The adequacy of such facilities to handle the output of the nuclear industry is beyond the scope of this study. However, it should be noted that the CCF/FRP is designed to handle the output of only one FRP, while several FRP's are expected to start operation during the $1980^{\circ} \mathrm{s}$. The CCF/RSSF is of larger capacity to handle the output from more than one FRP; however, the CCF/RSSF is also of limited capacity and would not handle the total industry output of calcine much beyond 1986.

Cost estimate summaries for the two facilities are given on Tables 8-1 and 8-2.

\subsection{CONSTRUCTION SCHEDULE}

The construction schedule is based on project funding in fiscal year 1977 with hot start up in January 1983. Time for licensing the facility in accordance with $10 \mathrm{CFR} 70$ is included. The CCF construction schedule (Figure 8-1) shows two concurrent schedules, one for process equipment and a second for the facility. The process equipment schedule is time consuming because a large percentage of such equipment is of new design, or must be adapted to remote operation. This operation requires careful integration. But, the time required for the integrated schedule is expected to be no longer than the requirements for a single facility construction schedule. 
TABLE $8-1$

\section{CCF/RSSF \\ SUMMARY ESTIMATE OF COST \\ (\$ millions)}

DESCRIPTION

Construction cost

Yardwork

CCF Building

CCF Filter, Fan House

\& stack

Communications \& Alarm

Instrumentation

Canisters

Checkout, Vendor's

Assistance \& startup

Production Equipment (N.S.C.)

Including Indirect costs

Total Direct cost

Indirect Cost*

TOTAL CONSTRUCTION COST

Design Engineering \& $A / E$

License Fee

\section{Contingency}

Construction \& Indirect cost Engineering

Production Equipment (N.S.C.)

subtotal

Escalation

Construction, Indirects, License \& Contingency

Engineering pitle I Engineering Title II Engineering Title III

Production Equipment

(N.S.C.)

TOTAL PROJECT COST
AMOUNT

TOTAL
0.1

15.0

1.0

1.5

2.5

0.4

0.5

6.0
7.6

1.2

2.2
11. 0

$\$ 52.0$

20.0

0.5

1.7

0.8

5.0

*Indirect cost based on Total Direct Cost, excluding the Production Equipment (N.S.C.) which includes applicable Indirect costs. 


\section{TABLE $8-2$ \\ CCF/FRP \\ SUMMARY ESTIMATE OF COST \\ (\$ millions)}

DESCRIPTION

Construction cost

Yardwork

CCF Building

CCF Filter, Fan House

\& stack

Communications \& Alam

Instrumentation

Canisters

Checkout, Vendor's

Assistance \& Startup

production Equipment (N.S.C.)

Including Indirect costs

Total Direct Cost

Indirect Cost*

TOTAL CONSTRUCTION COST

Design Engineering \& $\mathrm{A} / \mathrm{E}$

Iicense Fee

Contingency

Construction \& Indirect cost Engineering

Production Equipment (N.S.C.) Subtotal

Escalation

Construction, Indirects,

License contingency

Engineering Title I

Engineering Title II

Engineering Title III

Production Equipment

(N.S.C.)

TOTAI PROJECT COST

a. 26

a. 42

@. 57
AMOUNT

TOTAL
0.4
11.5
0.6
1. 6
1. 9
0.4
0.5
3.1

6.5

1. 0

1.2

8.7

$\$ 40.0$

15.6

0.3

1. 1

0.5

20.0

2.5

$\$ 60.0$

*Indirect Cost based on Total Direct Cost, excluding the Production Equipment (N.S.C.) which includes applicable Indirect Costs. 


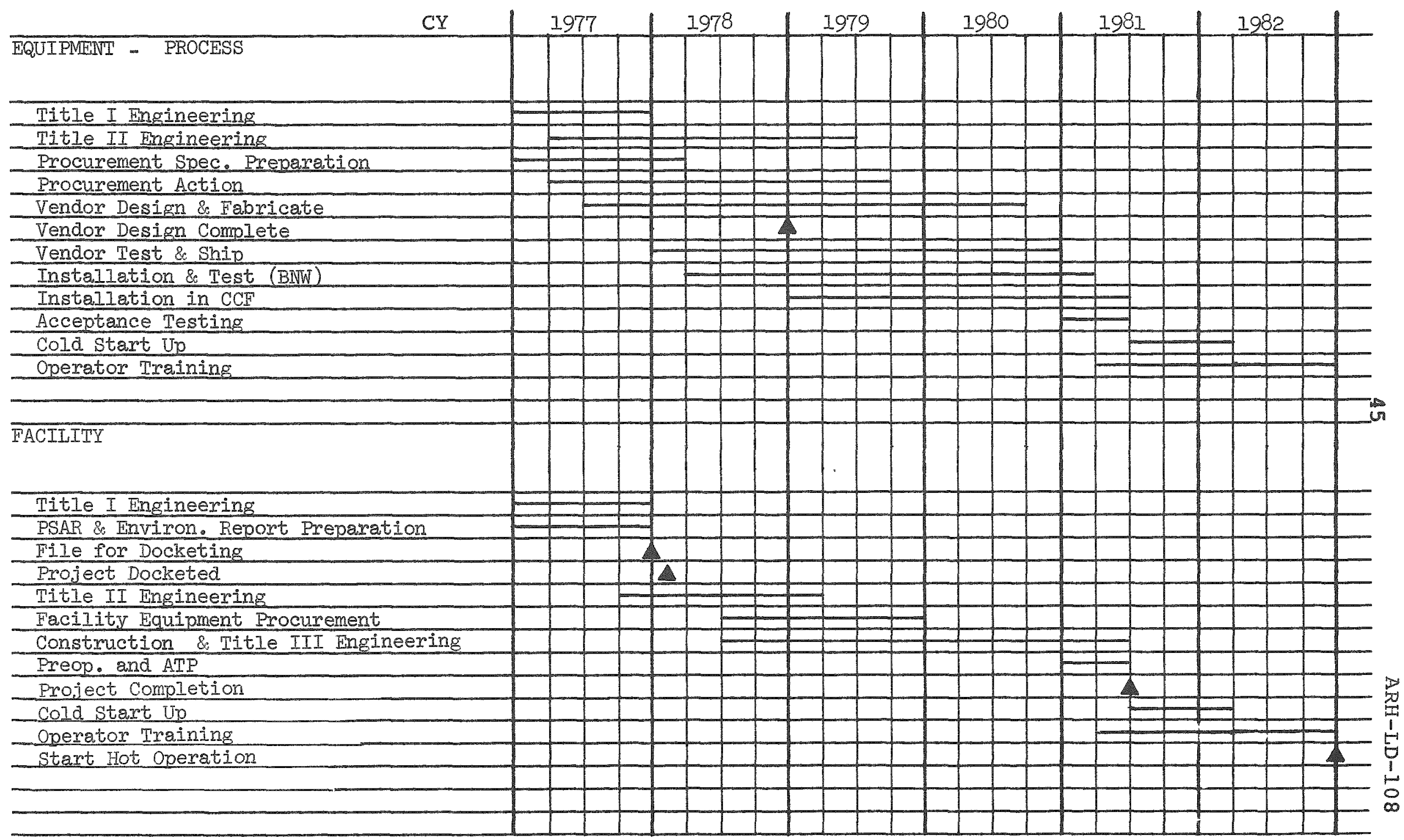

FIGURE $8-1$

CCF CONSTRUCTION SCHEDULE

(Based on licensing under 10 CFR 70) 


\subsection{OPERATING COSTS}

No dollar value has been placed on the operating cost of the two facilities; however, a few of the more significant items to be considered in the comparison of the two concepts are given below.

- Both CCF's will be adjacent to a large facility performing related work. This will permit them to share manpower, supervision, personnel facilities, etc., with the basic facility to about the same degree.

- The CCF/RSSF will be required to receive incoming canisters of calcine, which must be stored, opened, emptied, and refilled while the CCF/FRP will receive calcine through a pipe and process it immediately. These operations at the CCF/RSSF will require additional operations and maintenance personnel.

- The incoming canisters at the RSSF are not expected to be satisfactory as the final glass containment barrier, at least initially, because their condition cannot be verified prior to filling with glass. As a result, an overpack container of known quality will be added to each unit. The overpack canisters represent a substantial extra-material cost. 


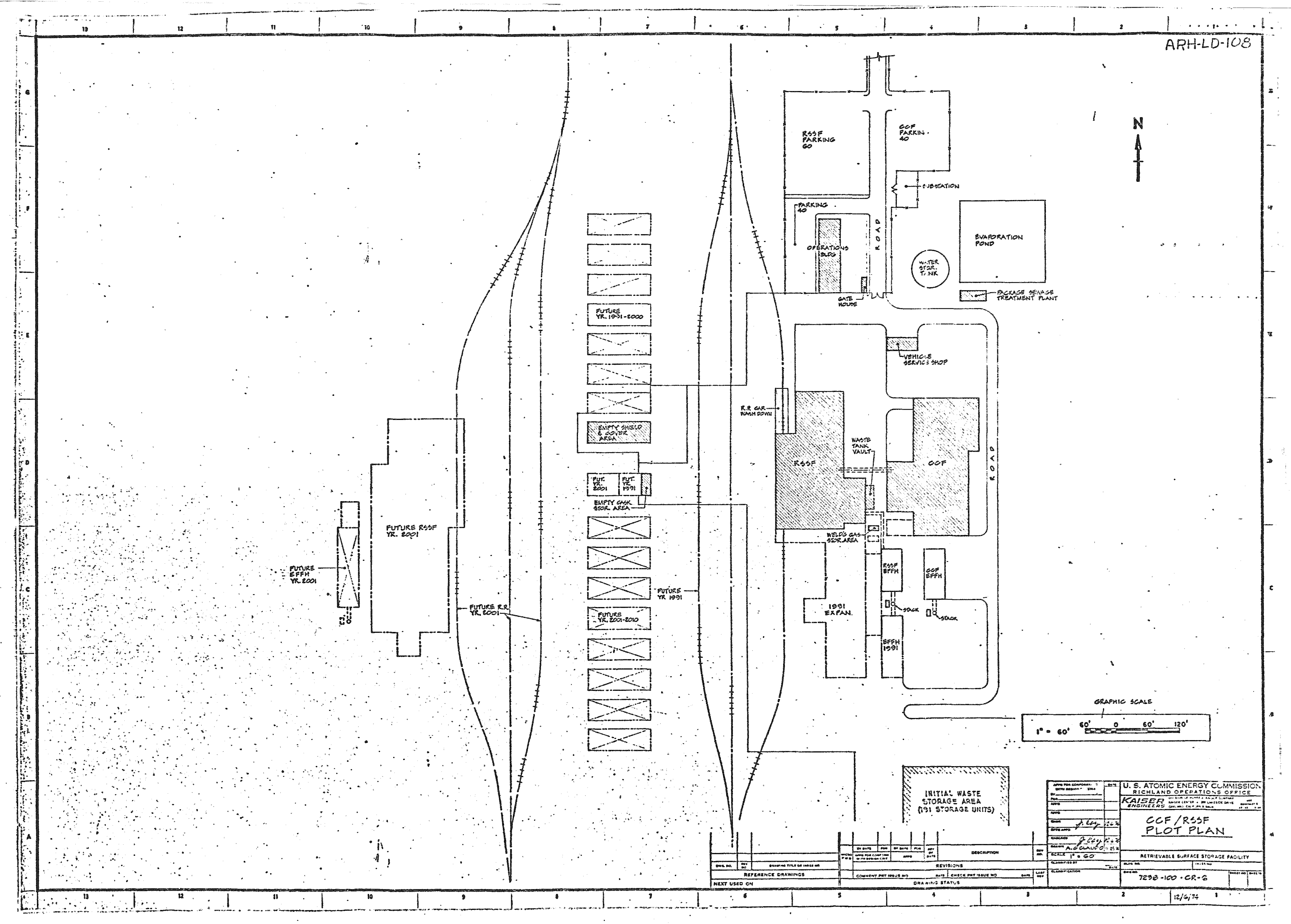




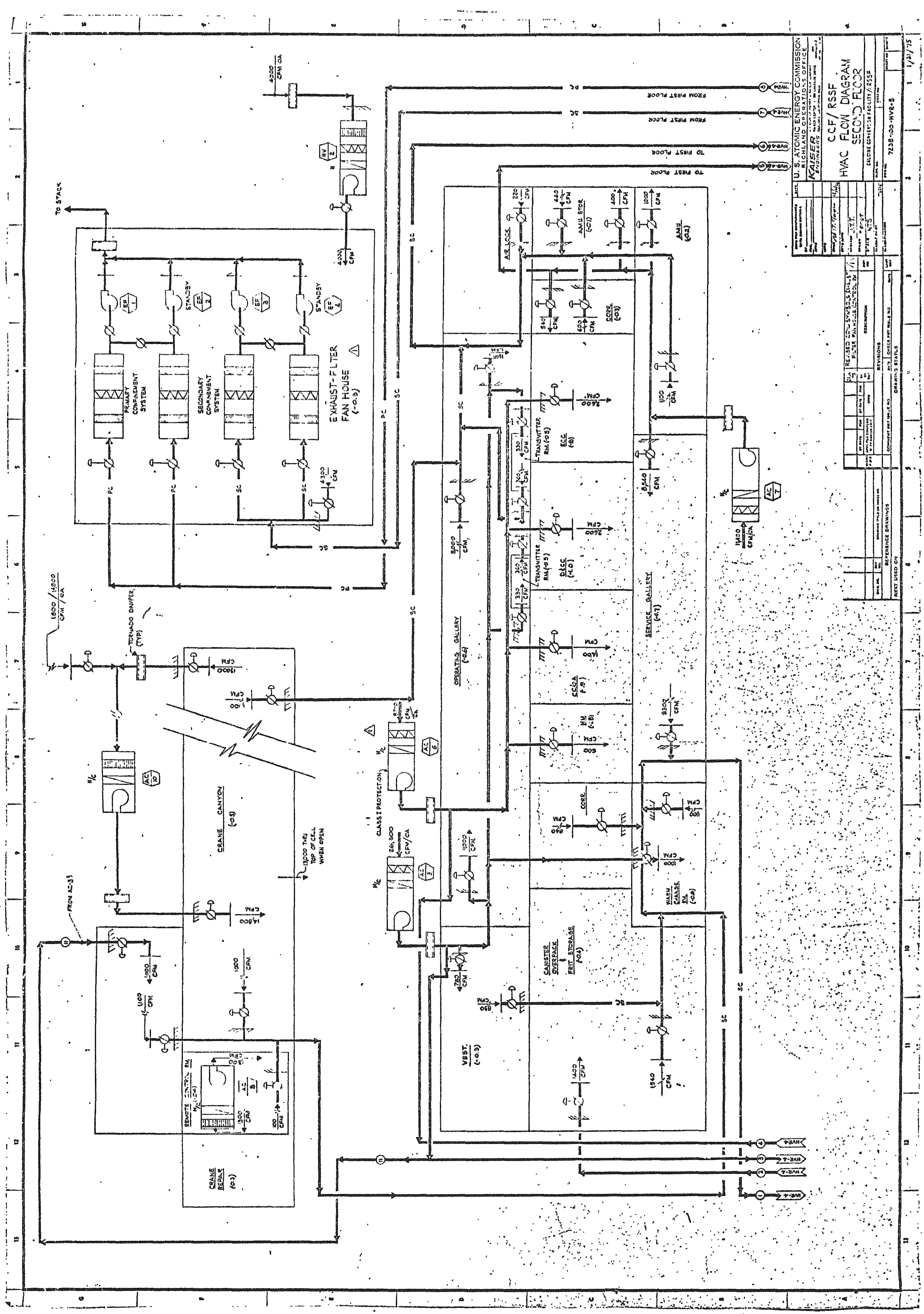




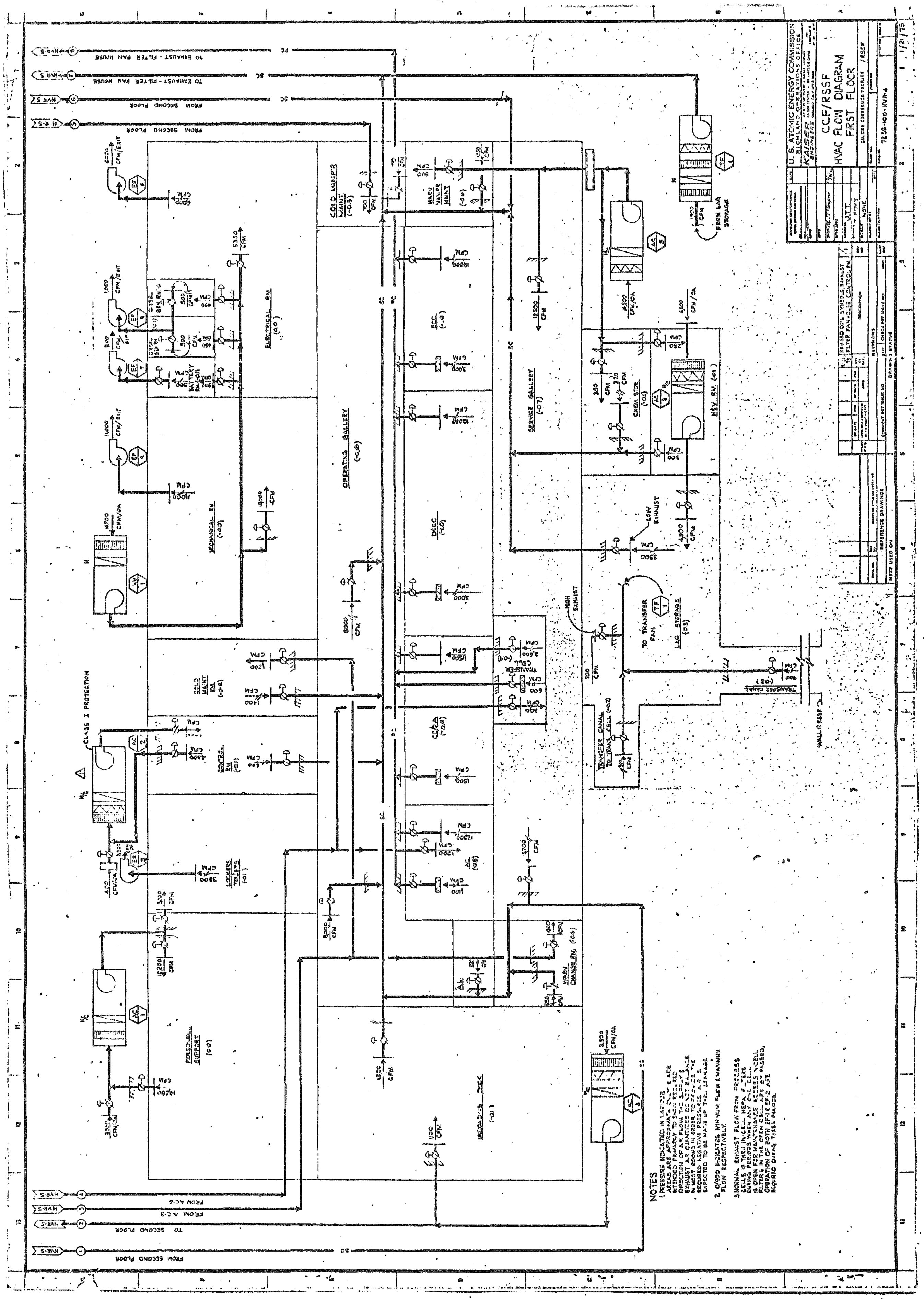




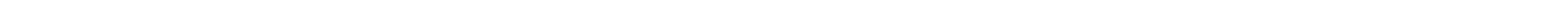



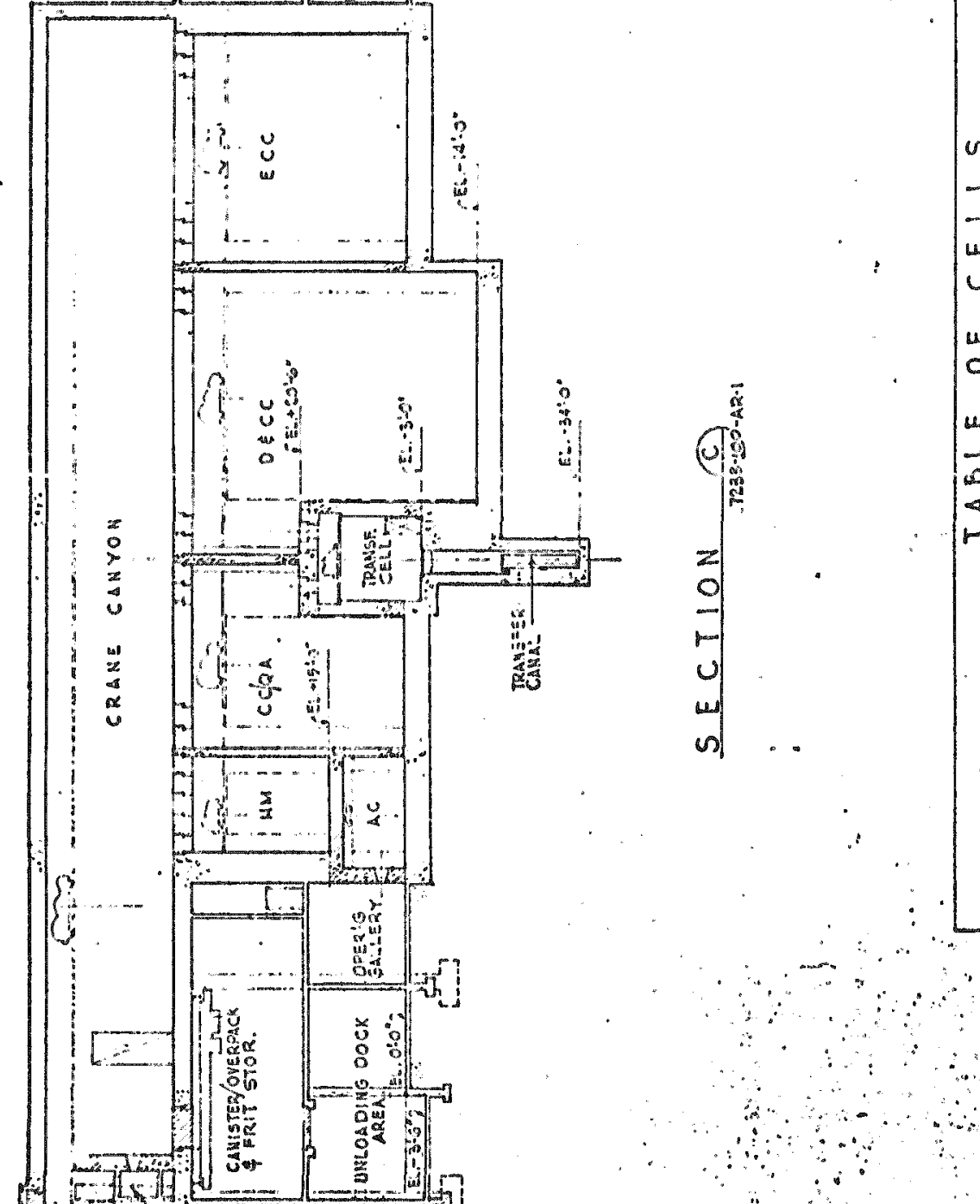

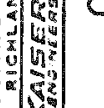

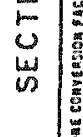

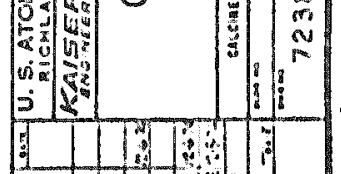

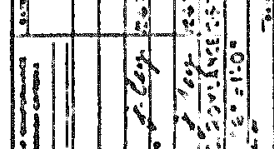

M111:
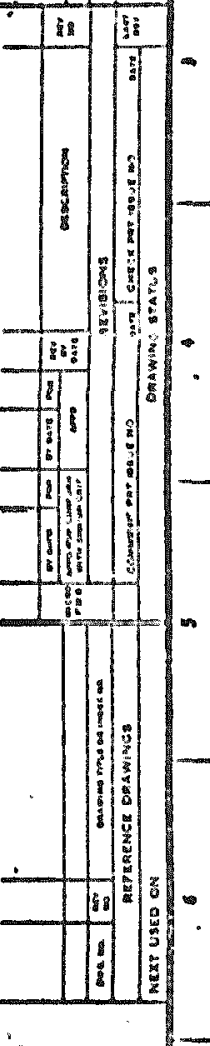

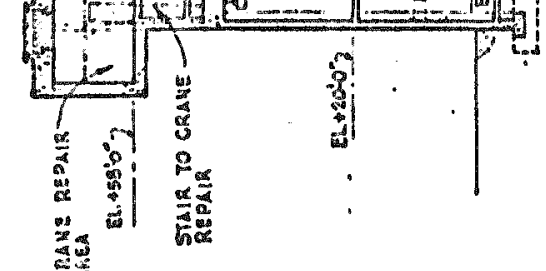
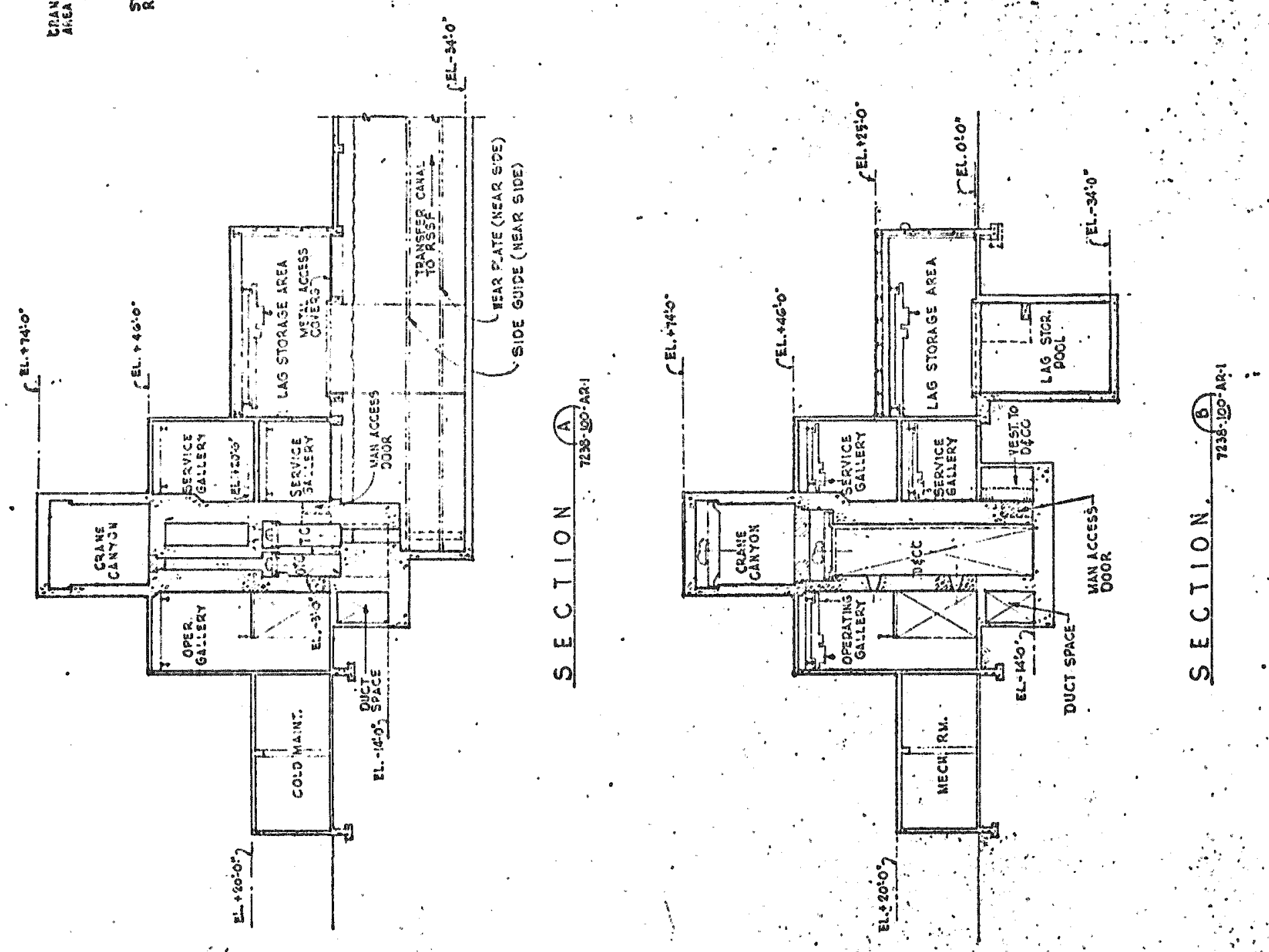


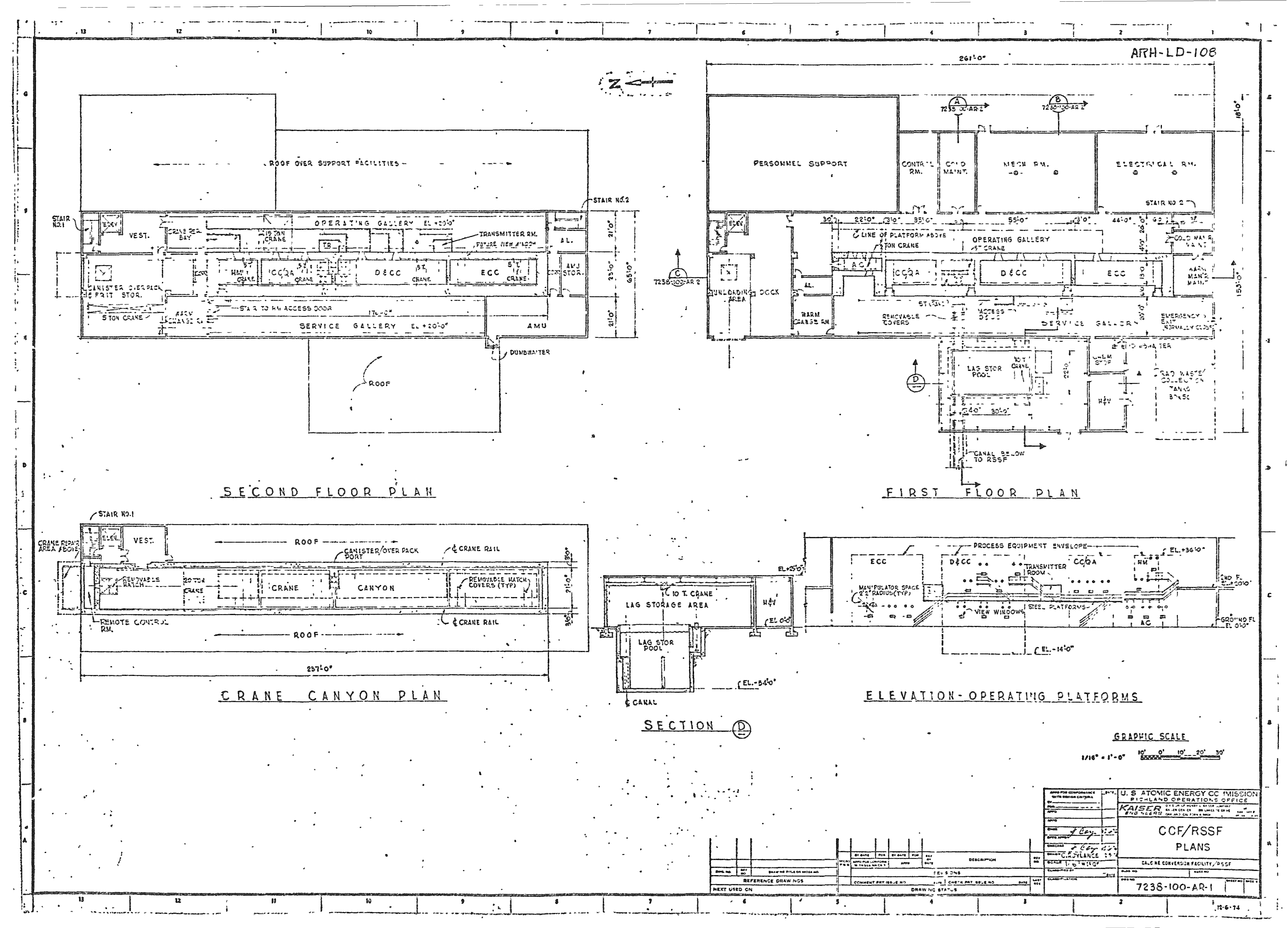




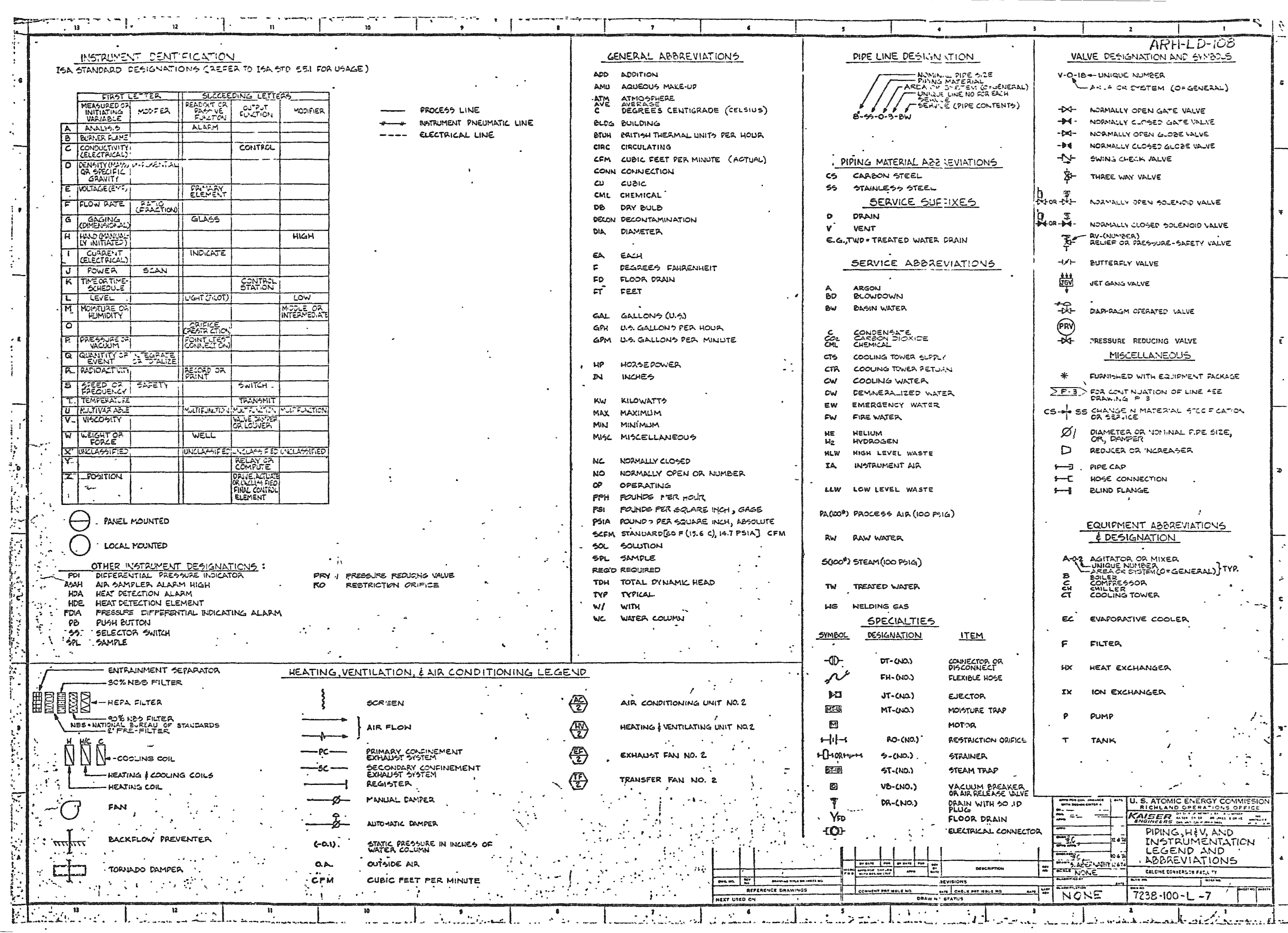




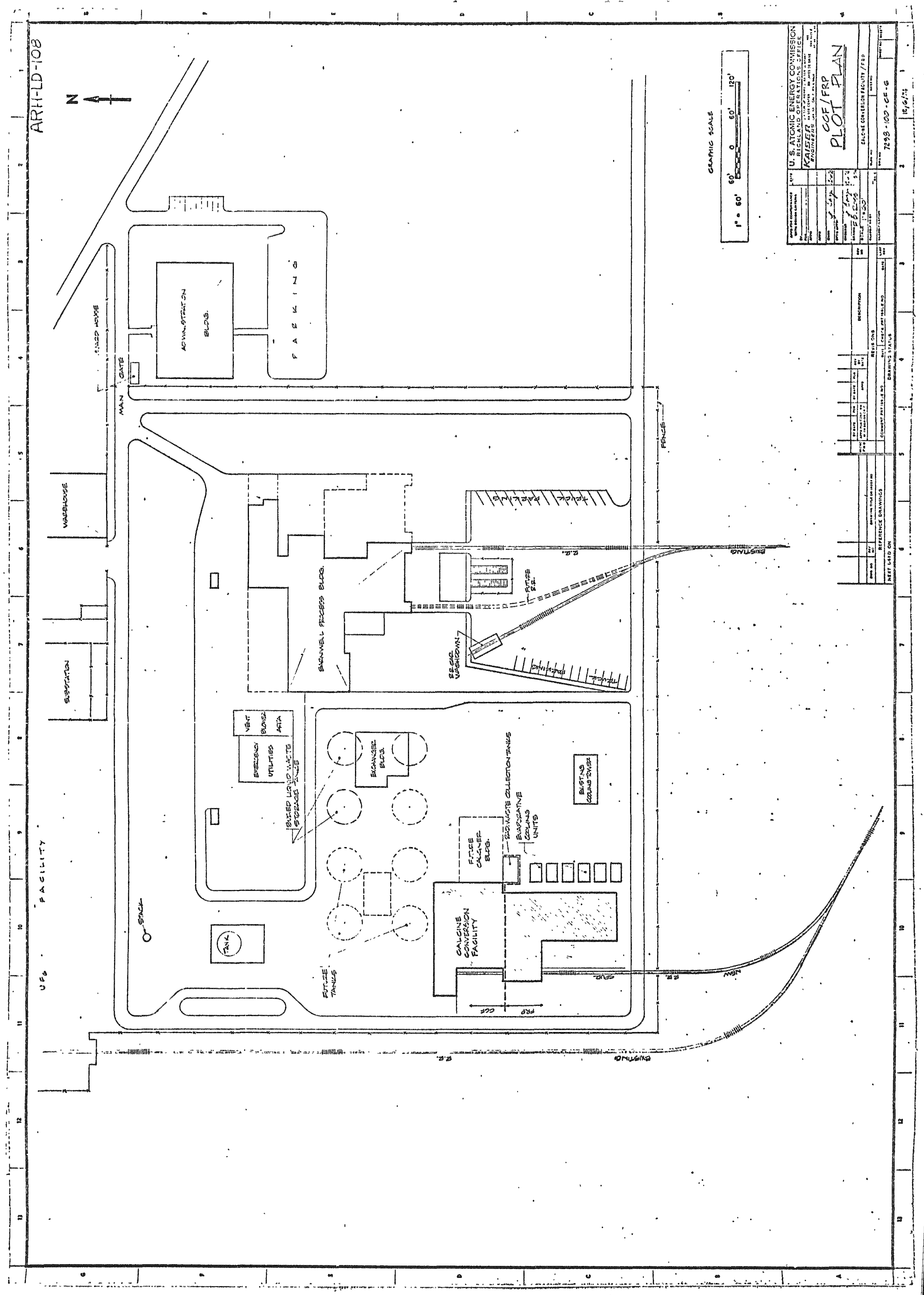




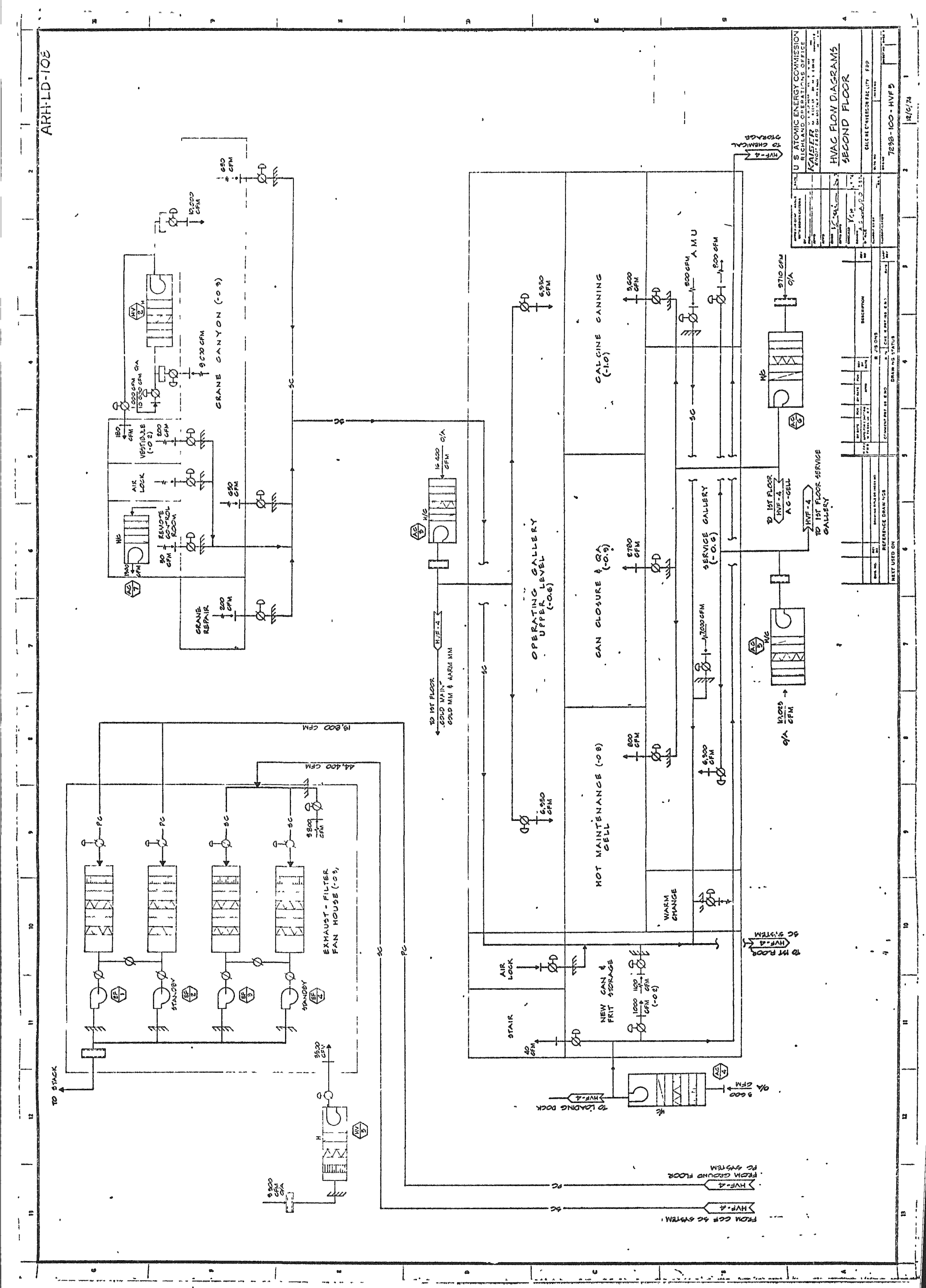




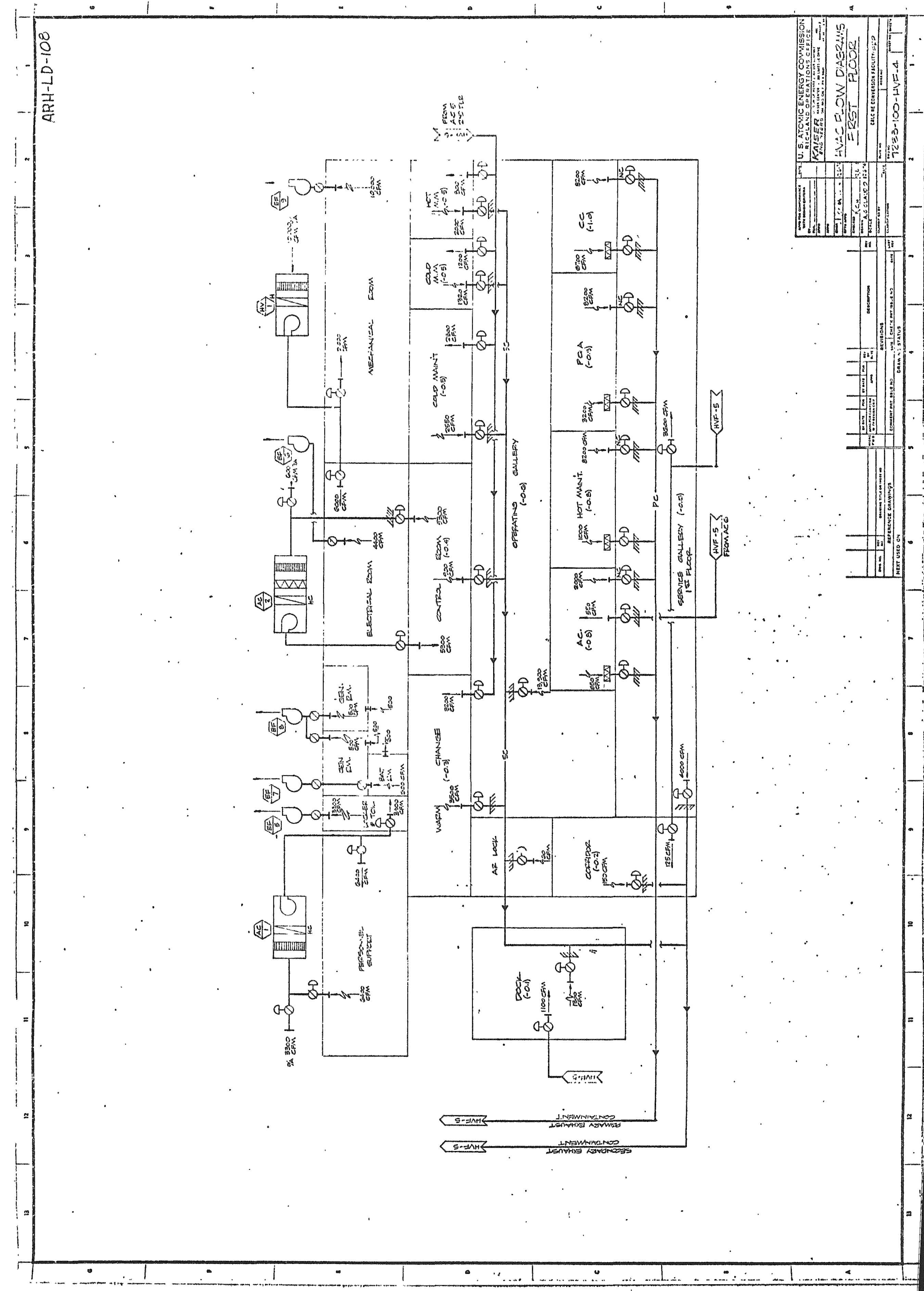




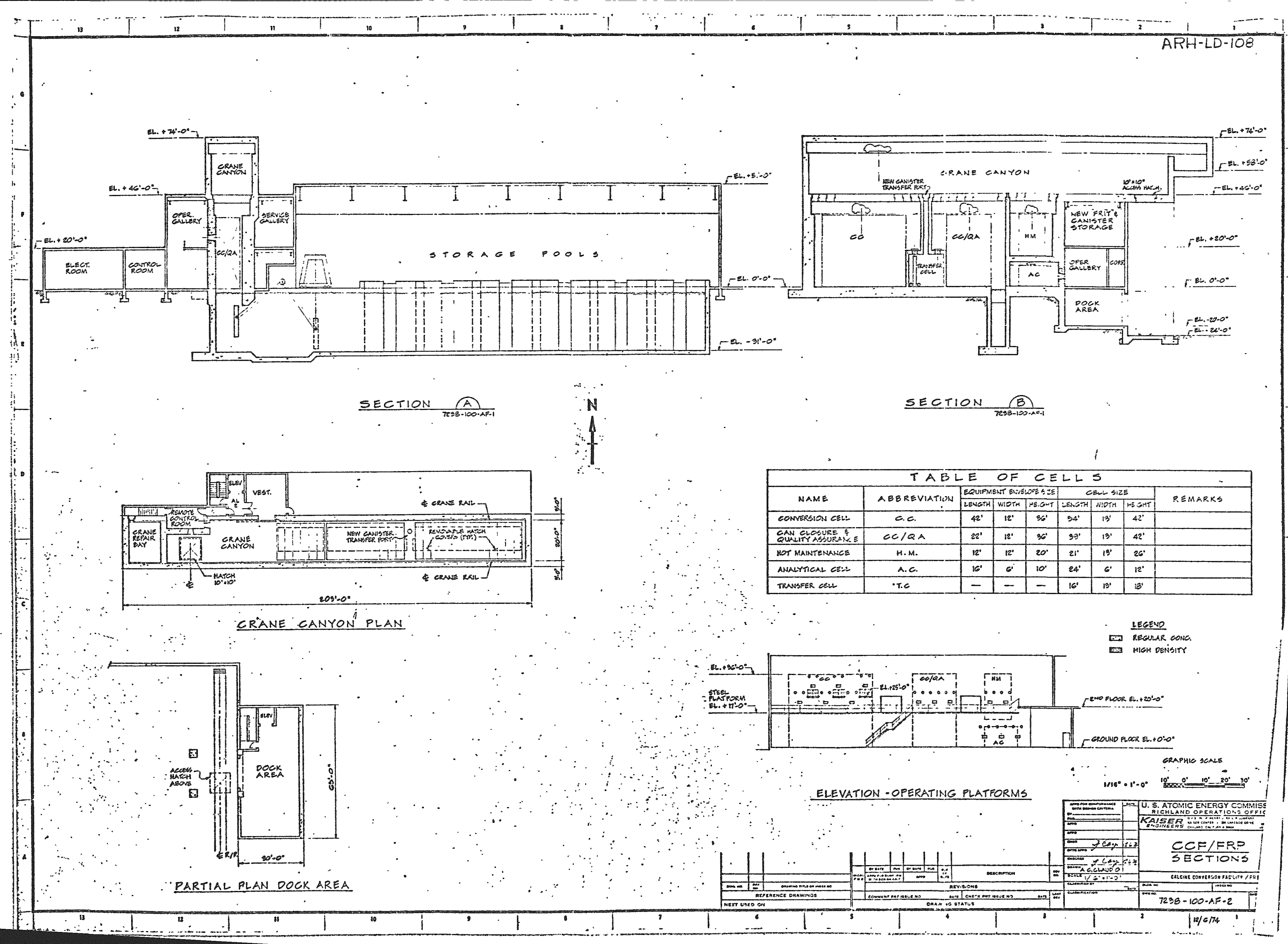




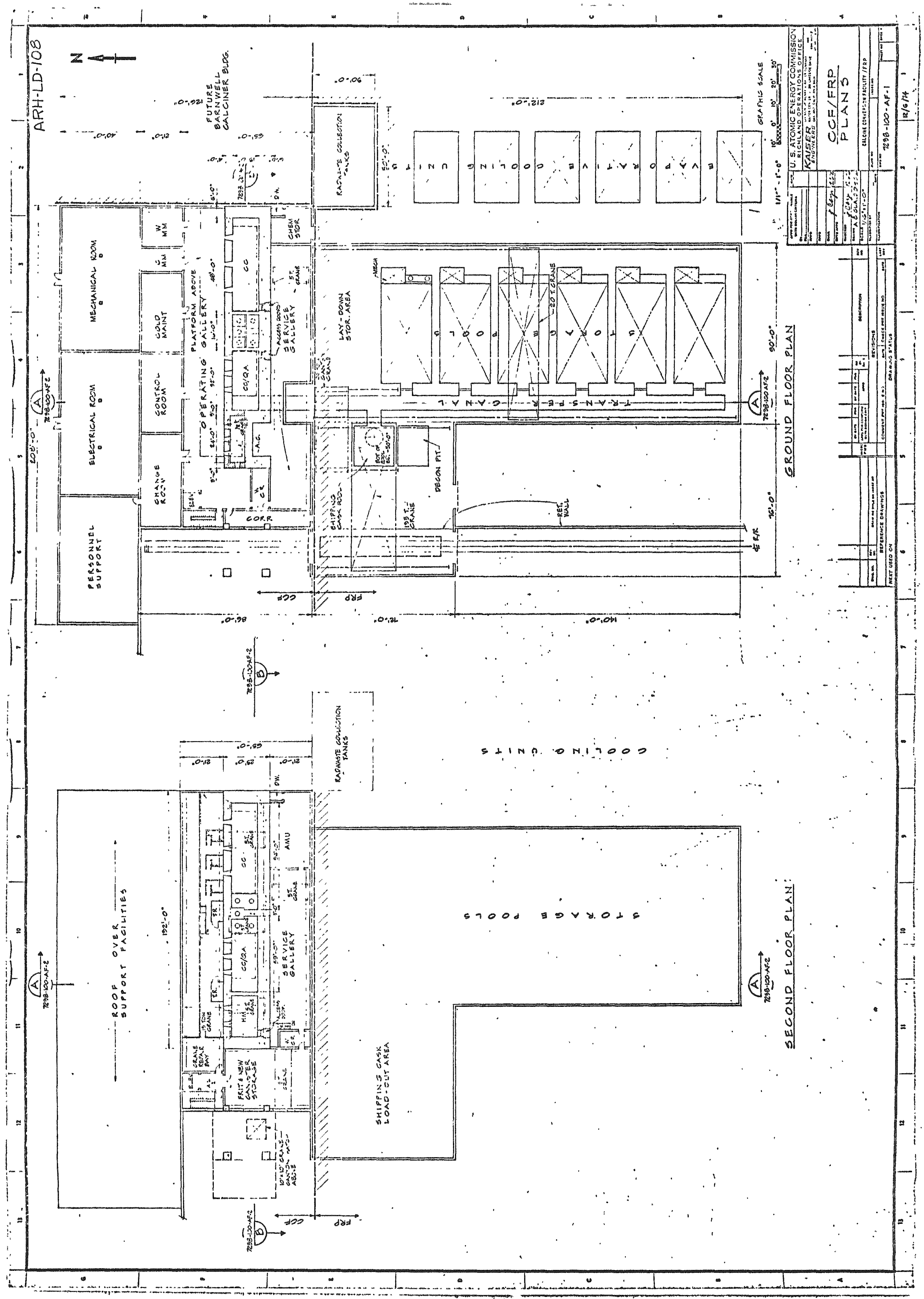

